\title{
Cdk3-promoted epithelial-mesenchymal transition through activating AP-1 is involved in colorectal cancer metastasis
}

\author{
Jinping Lu ${ }^{1, *}$, Zhen Lin Zhang ${ }^{1, *}$, Damao Huang ${ }^{2, *}$, Na Tang ${ }^{3}$, Yuejin $\mathrm{Li}^{1}$, Zhengke \\ Peng $^{1}$, Chengrong Lu ${ }^{3}$, Zigang Dong ${ }^{4}$ and Faqing Tang ${ }^{1,2}$ \\ ${ }^{1}$ Clinical Laboratory and Medical Research Center, Zhuhai Hospital of Jinan University, Zhuhai People's Hospital, Zhuhai, P.R. \\ China \\ ${ }^{2}$ Clinical Laboratory, Xiangya Hospital of Central South University, Changsha, P.R. China \\ ${ }^{3}$ Institution of Pathogenic Biology, Medical College, University of South China, Hengyang, P.R. China \\ ${ }^{4}$ Hormel Institute, University of Minnesota, Austin, Minnesota, USA \\ * These authors have contributed equally to this work \\ Correspondence to: Faqing Tang, email: tangfaqing33@hotmail.com \\ Keywords: Cdk3, colorectal cancer, AP-1, epithelial-mesenchymal transition, metastasis \\ Received: August 16, $2015 \quad$ Accepted: January 04, $2016 \quad$ Published: January 09, 2016
}

\section{ABSTRACT}

Cyclin dependent kinase-3 (Cdk3) is a positive regulator of the $\mathbf{G} 1$ mammalian cell cycle phase. Cdk3 is involved in cancer progression, but very little is known about its mechanism in cancer development and progression. Herein, we found that Cdk3 increased colorectal cancer metastasis through promoting epithelial-mesenchymal transition (EMT) shift. Cdk3 was found to highly express in metastatic cancer and induce cell motility and invasion. Cdk3 was shown to phosphorylate c-Jun at Ser 63 and Ser 73 in vitro and ex vivo. Cdk3-phosphorylated c-Jun at Ser 63 and Ser 73 resulted in an increased AP-1 activity. Ectopic expression of Cdk3 promoted colorectal cancer from epithelial to mesenchymal transition conjugating AP-1 activation, while AP-1 inhibition dramatically decreased Cdk3-increased EMT shift. These results showed that the Cdk3/c-Jun signaling axis mediating epithelial-mesenchymal transition plays an important role in colorectal cancer metastasis.

\section{INTRODUCTION}

Colon cancer is one of the most common malignancies worldwide, with about 1.2 million new cases and 608,700 deaths every year [1,2]. In the United States, an estimated 40,000 new cases of rectal cancer occurred, and an estimated 50,310 people died from rectal and colon cancer combined in 2014 [3]. In Eastern Asia, rectal cancer occurs in more than 16 per 100,000 individuals per year and accounts for more than 168,000 death $[3,4]$. Colorectal cancer is one of the major death causes, being the third most common diagnosed cancer in men and the second in women [5], and metastasis is the main factor of colorectal cancer death [6, 7]. Synchronous distant metastases is already observed in about $30 \%$ of colorectal cancer patients, and at least a further third develops metachronous metastases despite primary treatment with curative intention $[6,8]$. Therefore, development of distant metastases is the most crucial and lethal event, critically limiting therapy options $[9,10]$.
Metastasis is a complex process, going along with strong morphological and functional changes of tumor cells [11]. One of the earliest steps of metastasis is to escape from the primary tumor to invade surrounding blood vessels [12]. Epithelial-to-mesenchymal transition (EMT) is critical for tumor cell invasion and dissemination. Many factors are involved in development and progression of colorectal cancer metastasis, but its mechanism is still not clear. The transcription factor Forkhead box M1 (FOXM1) overexpression was significantly associated with lymph node metastasis, its downregulation inhibited cell migration and invasion in vitro. In mechanism, its downexpression reversed EMT phenotype by up-regulating E-cadherin, reduction vimentin and snail expressions [13]. SOX9 bound to and activated S100P promoter. Knockdown of SOX9 expression decreased S100P expression, resulting in the reduced invasiveness and metastasis of colon cancer cells by inhibiting EMT shift [14].

Cyclin-dependent kinase $(\mathrm{Cdk} 3)$ is a kinase that 
enhances progression through G1 into $\mathrm{S}$ phase in the mammalian cell cycle [15-17]. Cdk3 activation appears early in G1-phase [18] and peaks at mid G1 [15], and is required for entry into S-phase [16]. During G1/S transition, Cdk3 binds to E2F-1, E2F-2, or E2F-3 through DP-1 and enhances their transcriptional activities [19], thus playing an essential role at the G1/S transition. More importantly, Cdk3 highly expresses in various cancer [20-22], and its expression is associated with the degree of infiltration, lymph node metastasis and clinical staging $[21,22]$. As a positive regulator of $\mathrm{G} 1, \mathrm{Cdk} 3$ is involved in malignant cell transformation $[15,23]$. The previous works showed that Cdk3 phosphorylates c-Jun at Ser63/73 and increases AP-1 activity [24]. AP-1 activation induces EMT shift, and participates in cancer metastasis $[25,26]$. We speculated that Cdk3 may mediate AP-1 activation, promote EMT shift, and promote colorectal cancer metastasis. In the present study, we found that $\mathrm{Cdk} 3$ is highly expressed in metastatic colorectal cancer. It was confirmed that $\mathrm{Cdk} 3$ ectopic expression increases cell motility and invasion in vitro, enhances colorectal cancer metastasis ex vivo. Additionally, Cdk3 was also found to induce colorectal cancer cell from epithelial to mesenchymal transition through activating AP-1. Our data showed that $\mathrm{Cdk} 3$ is involved in colorectal cell metastasis.

\section{RESULTS}

\section{Expression of $\mathbf{C d k} \mathbf{3}$ in normal colorectal tissues, colorectal cancer and metastatic cancer tissues}

To know the relationship of $\mathrm{Cdk} 3$ and colorectal cancer metastasis, Cdk3 expression was detected using immunohistochemistry in formalin-fixed and paraffinembedded archival clinical tissues, including 52 cases of normal colorectal tissue, 87 cases of primary colorectal cancer, and 49 cases of metastatic colorectal cancer. The immunohistochemistry results revealed positive $\mathrm{Cdk} 3$ signals showing brown-yellow granules in the cytoplasm and nucleus (Figure 1A-b, c). Cdk3 staining scores were

A

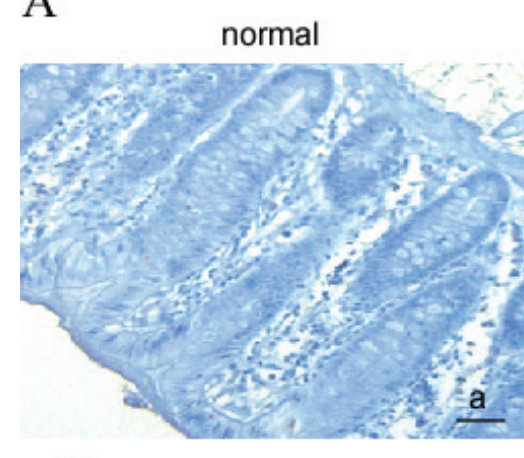

B

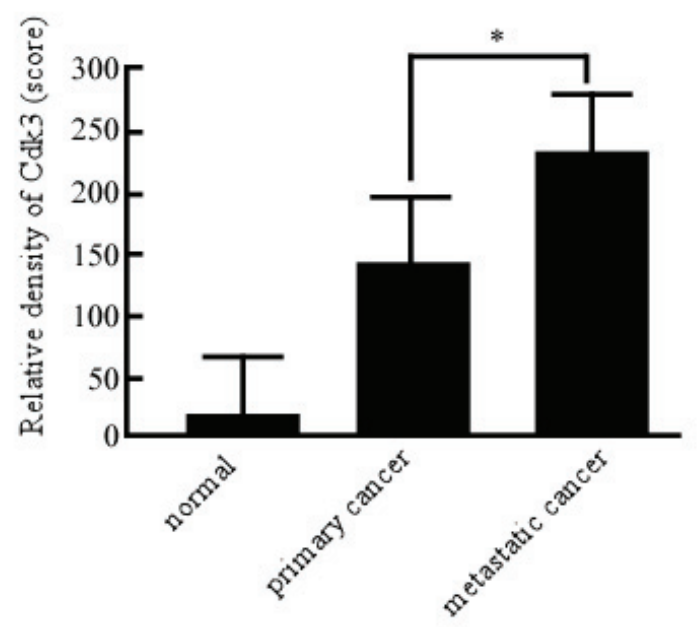

primary cancer

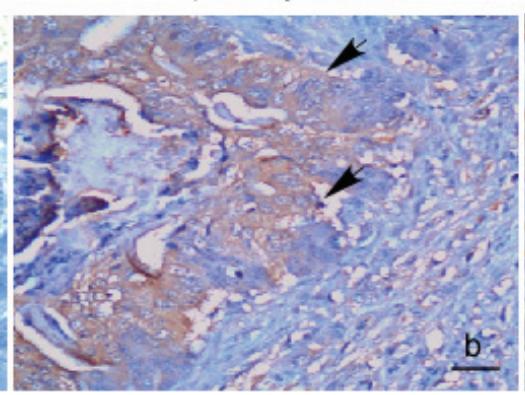

$\mathrm{C}$

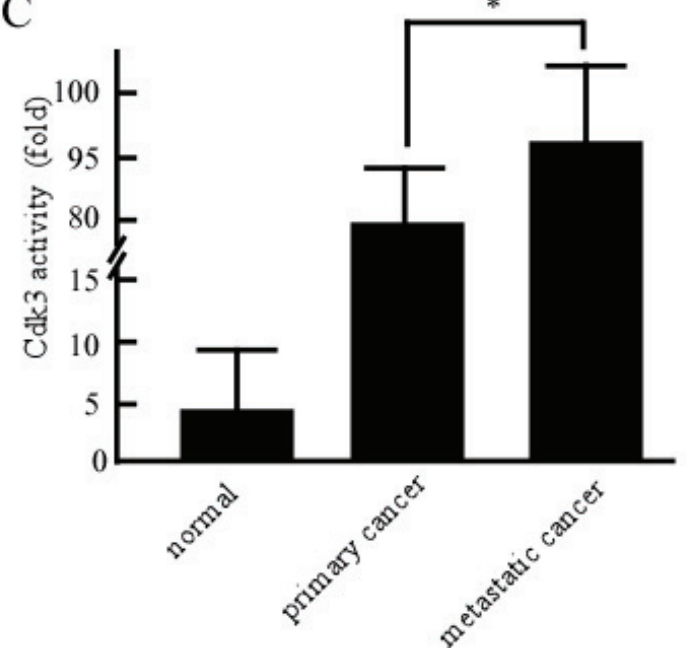

Figure 1: Cdk3 expression and activity in normal colorectal, primary cancer and metastatic cancer tissues. A. The formalin-fixed and paraffin-embedded tissue sections of normal colorectal tissues, colorectal primary cancer, and metastatic cancer were stained using a standard immunohistochemical technique. Cdk3 was stained with Cdk3 antibody in the tissues samples. Arrows, positive cells. Original magnification, $\times 200$. Scale bar, $10 \mu \mathrm{m}$. B. Evaluation of Cdk3 staining. Each case was rated according to a score that added a scale of intensity of staining to nucleus and cytoplasm. C. Cdk3 activity was detected in normal colorectal, primary and metastatic cancer tissues using vitro kinase assay as described in Material and methods. Three individual experiments and presented as mean $\pm \mathrm{SD}$. Statistical analysis was done using SPSS (version 18.0), a difference of $P<0.05$ was considered statistically significant.*, represented $P<0.05$. 
Table 1: Cdk3 expression in normal colon tissue, colon cancer and metastatic cancer

\begin{tabular}{|l|l|l|l|l|l|}
\hline Group & $\boldsymbol{n}$ & - & + & $\mathbf{\%}$ & $\boldsymbol{P}$ \\
\hline normal & 52 & 46 & 6 & 11.5 & \\
\hline primary cancer & 87 & 67 & 19 & 21.8 & 0.027 \\
\hline metastatic cancer & 49 & 8 & 41 & 83.7 & 0.001 \\
\hline
\end{tabular}

evaluated according to staining intensity and area in both nuclear and cytoplasm. The results showed that Cdk3 scores were stronger in metastatic cancer than that in primary cancer, and primary cancer being stronger than in normal colorectal tissues (Figure 1B). Furthermore, as shown in Table 1, the percentages of Cdk3 positive staining in normal, primary cancer and metastatic cancer tissues were respectively $11.5 \%, 21.8 \%$ and $83.7 \%$. Cdk3 protein expression was significantly increased in metastatic cancer compared to primary cancer $(P<$ 0.05 ). Additionally, the correlation of CDK3 expression with clinical features and prognosis of colorectal cancer patients was analyzed, Cdk3 expression is related with TNM grade (Supplemental Table, $P<0.05$ ). As a kinase, Cdk3 activity mainly contributes to Cdk3 function. Further, we detected Cdk3 activity in normal colorectal tissue, primary and metastatic cancer using in vitro kinase assay. The results showed that Cdk3 activity is the highest in metastatic cancer tissues, and being higher in metastatic cancer than that in primary one (Figure $1 \mathrm{C}, P<0.05$ ). This suggests that Cdk3 expression may be related to colon cancer progression.

\section{Cdk3 increases motility and invasion of colorectal cancer cells}

The above suggests that Cdk3 may be involved in colorectal cancer metastasis. Next step is to investigate whether Cdk3 increases the motility and invasion of cancer cell. HT29 cell, a colon cancer cell line with a low metastatic ability was transfected with pRcCMV-HA-Cdk3 (HA-Cdk3), and the stable expressed cell line, HT29-Cdk3 was obtained by selection for $\mathrm{G} 418$ resistance. Its motility and invasion was detected using Boden chamber invasion assay in vitro. HT29 cell had a low expression (Figure $2 \mathrm{~A}$, left lane in $3^{\text {rd }}$ panel) and activity of Cdk3 (Figure $2 \mathrm{~A}$, left lane in $1^{\text {st }}$ panel), and the expression (Figure $2 \mathrm{~A}$, right lane in $3^{\text {rd }}$ panel) and activity (Figure 2A, right lane in $1^{\text {st }}$ panel) of $\mathrm{Cdk} 3$ dramatically increased when being transfected with $\mathrm{Cdk} 3$. Boden chamber assay showed that HT29 cell had a low motility (Figure 2B-d) and invasion ability (Figure 2B-a), and the motility (Figure 2B-e) and invasion (Figure $2 \mathrm{~B}-\mathrm{b}$ ) ability significantly increased after being transfected Cdk3 (Figure 2B-(d, h), $P<0.05$ ). These results indicate that $\mathrm{Cdk} 3$ increases the motility and invasion of colorectal cancer cell. To further observe AP1 's effect on Cdk3-increasing motility and invasion, AP-1 activity was inhibited in HT29-Cdk3 using AP-1 inhibitor curcumin, the motility and invasion were measured.
After curcumin treatment, the motility (Figure 2B-g) and invasion (Figure 2B-c) dramatically decreased (Figure 2B$(\mathrm{d}, \mathrm{h}), P<0.05)$. AP-1 plays an important role in Cdk3increasing cell motility and invasion.

To eliminate cell-line specific phenomenon, we also used colorectal cancer cell lines HCT116 and SW480 to further investigate, HCT116 as high metastatic ability cell, and SW480 as low metastatic cell, and got the similarity results. Cdk3 increased SW480 motility and invasion (Supplemental Figure 1A, 1B), siCdk3 decreased HCT116 motility and invasion (Supplemental Figure 1C, 1D).

\section{Cdk3 knockdown decreases motility and invasion of colorectal cancer cells}

To confirm Cdk3's role in colorectal cancer metastasis, the motility and invasion of colorectal cancer cells was observed when Cdk3 knockdown. SW620 cell, a colon cancer cell line with a high metastatic ability was transfected with siRNA-Cdk3 (siCdk3). SW620-siCdk3 was obtained by selection for G418 resistance. SW620 cell had a high Cdk3 expression(Figure $2 \mathrm{C}$, left lane in $3^{\text {rd }}$ panel) and activity (Figure 2C, left lane in $1^{\text {st }}$ panel), and the expression (Figure 2C, middle lane in $3^{\text {rd }}$ panel) and activity (Figure 2C, middle lane in $1^{\text {st }}$ panel) of Cdk3 dramatically decreased when being transfected siCdk3. Boden chamber assay showed that SW620 cell had a high motility (Figure 2D-e) and invasion ability (Figure 2D-a), and the motility (Figure 2D-f) and invasion (Figure 2D-b) ability significantly decreased in the transfect with siCdk3 (Figure 2D-d,h $P<0.05$ ). To further confirm Cdk3's role in cell motility and invasion, a rescue experiment for Cdk3 knockdown was conducted, SW620-siCdk3 were transfected with pRcCMV-Cdk3. The results showed that cell motility (Figure 2D-g) and invasion (Figure 2D-c) were increased after being transfected with Cdk3 (Figure 2D-d,h $P<0.05)$. SW620-siCdk3 regained motility and invasion ability after $\mathrm{Cdk} 3$ rescue. These data indicate that Cdk3 may play an important role in colorectal cancer metastasis.

\section{Cdk3 binds to and co-localizes with c-Jun}

Our previous works showed that $\mathrm{Cdk} 3$ activates AP-1 through binding to c-Jun in its mediating cell transformation. To confirm whether $\mathrm{Cdk} 3$-activating AP-1 exists in cancer metastasis, we co-transfected pHis6-tagged c-Jun (His-c-Jun) and pRcCMV-HA-Cdk3 


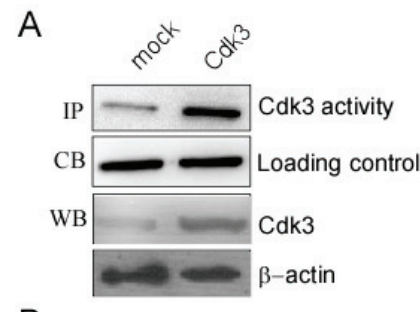

B

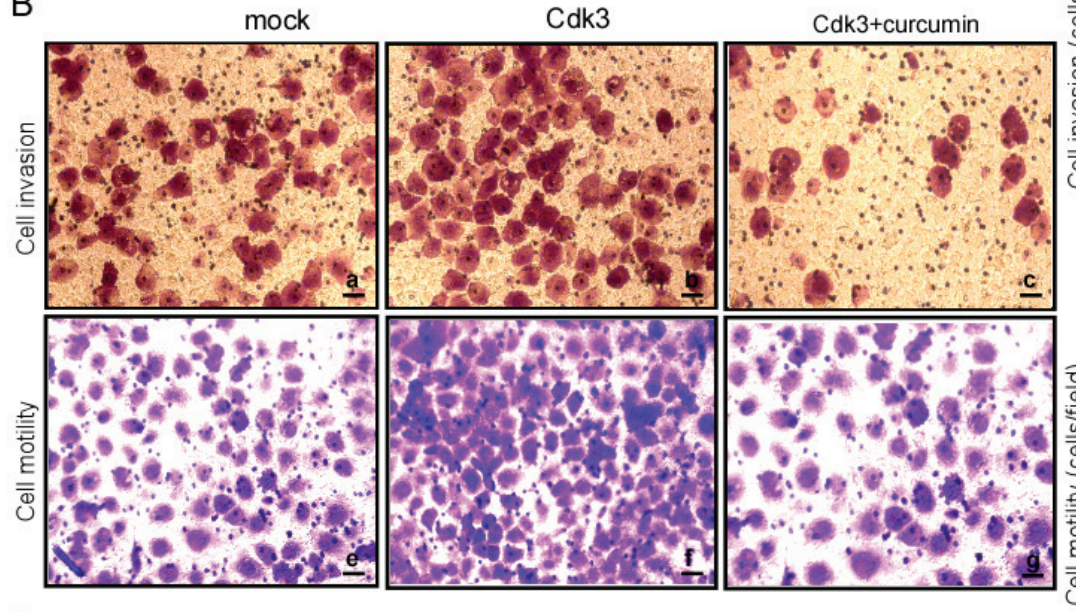

C

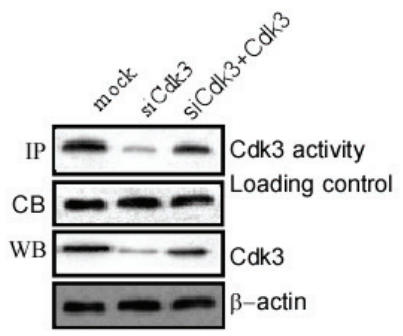

D
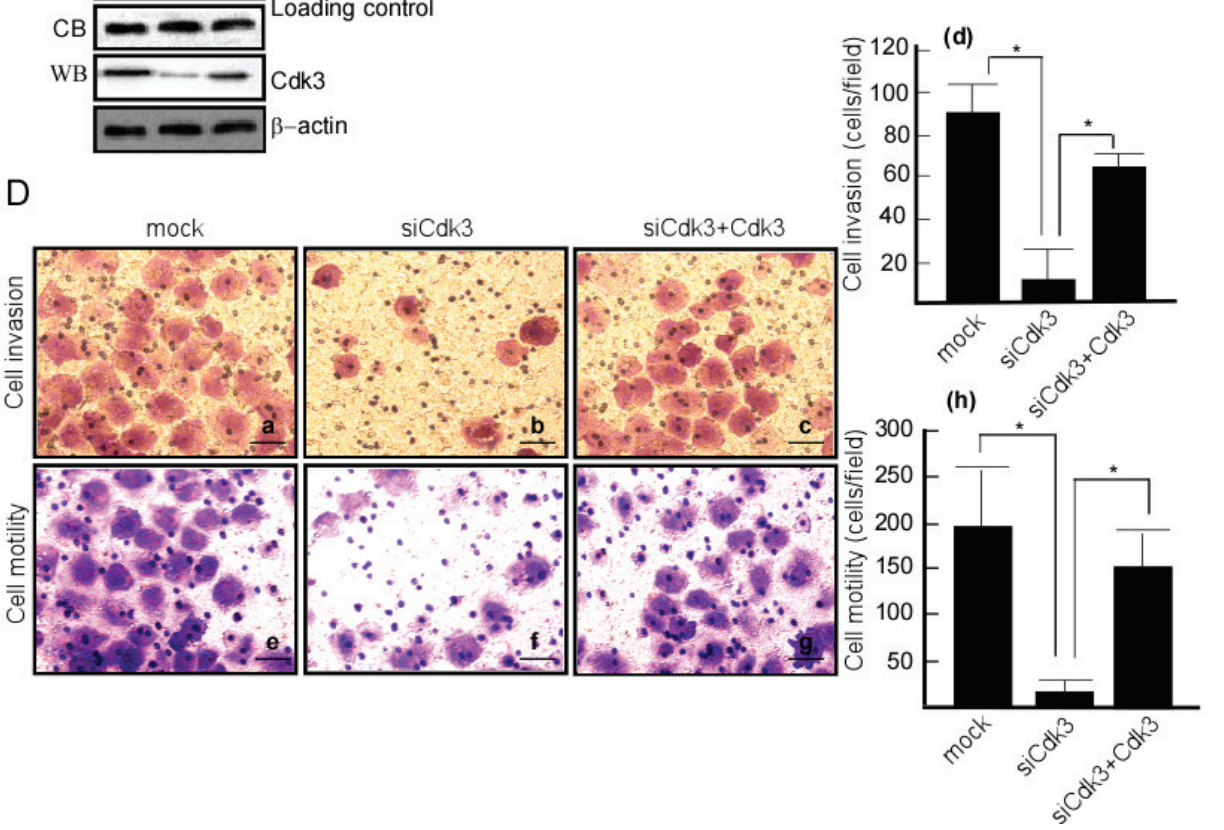

Figure 2: Cdk3 increases the motility and invasion of colorectal cancer cells. A. Cdk3 expression was detected in HT29Cdk3 and HT29-mock using Western-blotting. Cdk3 activity was detected using the immunoprecipiptation and in vitro kinase assay. B. Matrigel-coated Boyden chamber was used to measure the invasion of HT29-mock (a), HT29-Cdk3 (b), and HT29-Cdk3 with curcumin treatment (c). Random fields of view were counted to determine the number of invading cells (d). The uncoated Boyden chamber was used to determine these cells motility (e, f, g) and random fields were counted to determine the number of motility cells (h). C. Cdk3 expression and activity were detected in SW620-simock, SW620-siCdk3 and SW620-siCdk3 with Cdk3 transfection. D. The invasion of SW620simock (a), SW620-siCdk3 (b) and SW620-siCdk3 with Cdk3 transfection was detected (c). The invasion cells were counted (d). The motility of SW620-simock (a), SW620-siCdk3 (b) and SW620-siCdk3 with Cdk3 transfection was detected (e, f, g), and the motility cells were counted (h). Original magnification, $\times 400$. Scale bar $=20 \mu \mathrm{m}$. The cells were counted in three individual experiments and presented as mean $\pm \mathrm{SD}$. *, represented $P<0.05$. Coommassie blue staining and $\beta$-actin served as a loading control. IP, immunoprecipiptation assay; $\mathrm{CB}$, Coommassie blue staining; WB, Western-blotting analysis. *, represented $P<0.05$. 
(HA-Cdk3) into HEK 293 cells. These transfects were used for immunoprecipitation with HA antibody, and the immunocomplex was detected by Western-blotting with the His antibody or HA antibody. His-c-Jun was detectable in the immunocomplex (Figure 3A, lane 3 in upper panel), simultaneously, Cdk3 was also detected in the immunoprecipitation (Figure 3A, lane 3 in down panel). These results show that Cdk3 could bind to c-Jun.

Because endogenous Cdk3 levels are extremely low in most cell types [17], Cdk3- stable expressed cell line, HT29-Cdk3 cell was used in the next experiments. Cdk3 was immunoprecipitated from HT29-Cdk3 with $\mathrm{Cdk} 3$ antibody, and c-Jun and $\mathrm{Cdk} 3$ proteins in the immunocomplex were analyzed by Western-blotting. c-Jun was detectable in anti-Cdk3 precipitates (Figure 3B, lane 2 in upper panel). Furthermore, c-Jun was immunoprecipitated with c-Jun antibody, Cdk3 was detectable in the c-Jun immunocomplex (Figure 3C, lane 2 in upper panel). These results indicate that endogenous Cdk3 binds with c-Jun in HT29-Cdk3 cell.

Next, we determined whether Cdk3 co-localizes with c-Jun. Cdk3 and mock stably-transfected cells were stained with Texas Red to detect c-Jun and fluorescein- isothiocyanate (FITC) for detecting Cdk3 by immunofluorescence. The results indicate that $\mathrm{Cdk} 3$ co-localizes with c-Jun in the nucleus (Figure 3D, left $3^{\text {rd }}$ panel).

\section{Cdk3 phosphorylates c-Jun and increases AP-1 activity}

To determine whether Cdk3 phosphorylates c-Jun, an in vitro kinase assay was conducted using active $\mathrm{Cdk} 3$ as the kinase and a GST-c-Jun fusion protein as the substrate. c-Jun phosphorylated by Cdk3 was determined by Western-blotting analysis using specific phosphorylated antibody against c-Jun Ser63 or Ser73. Active JNK1 and GST-c-Jun served as a positive control (Fig 4A, lane 3 in $1^{\text {st }}$ and $2^{\text {nd }}$ panels). Results showed that Cdk3 could phosphorylate c-Jun at Ser63 (Figure 4A, lane 2 in $1^{\text {st }}$ panel) and Ser73 (Figure 4A, lane 2 in $2^{\text {nd }}$ panel). To further confirm Cdk3 phosphorylating c-Jun, pHis6-tagged c-Jun and pRcCMV-HA-Cdk3, pRcCMV-HA-Cdk3-DN (Dominant negative mutant) or pRcCMV-HA (mock) were transiently transfected into HEK 293 cells. Forty hours after transfection, $\mathrm{Cdk} 3$ protein expression was detected by Western-blotting analysis using specific antibodies. The phosphorylation of c-Jun at Ser 63 (Figure 4B, lane 3 in $3^{\text {rd }}$ panel) and c-Jun at Ser73 (Figure 4B, lane 3 in $4^{\text {th }}$ panel) could be detected in the cells transfected with c-Jun and $\mathrm{Cdk} 3$. No signal was detected in the cells transfected with c-Jun and Cdk3-DN (Figure 4B, lane 1 in $3^{\text {rd }}$ and $4^{\text {th }}$ panels), and it is weak in the cells transfected with c-Jun or mock (Figure $4 \mathrm{~B}$, lane 2 in $3^{\text {rd }}$ and $4^{\text {th }}$ panels) when
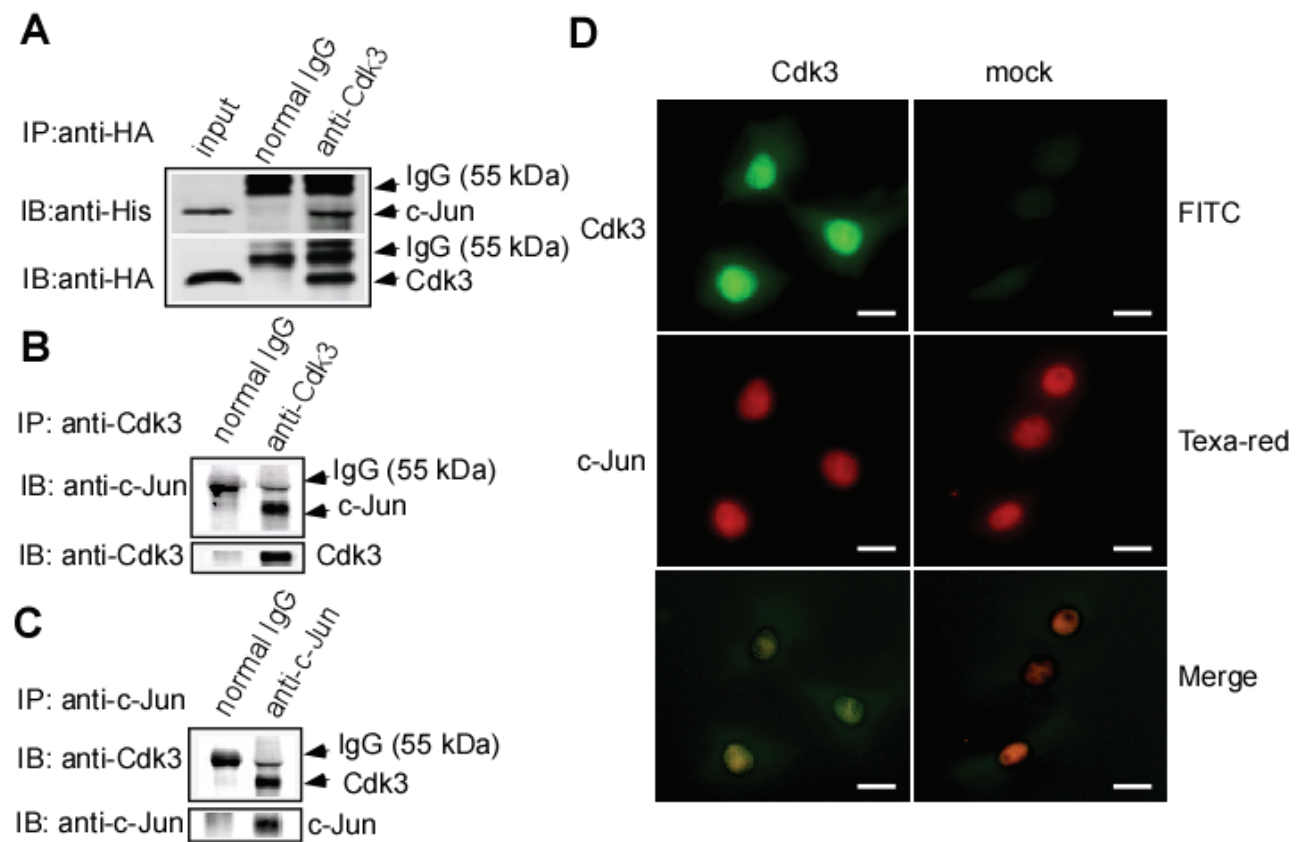

Figure 3: Binding of Cdk3 and c-Jun protein. A. Cdk3 binds to c-Jun in exogenous expression. pRcCMV-HA-Cdk3 and pHis6tagged c-Jun plasmids were transiently co-transfected into HCoEPiC cells. Cdk3 in His-tagged protein was detected by Western-blotting using anti-HA, and c-Jun was probed using anti-His. Inputs are representative of whole cell lysates. Precipitation with normal IgG served as a negative control. B. HT29-Cdk3 cells were used to investigate the binding of Cdk3 and c-Jun in endogenesis expression. Cdk3 in HT29Cdk3 or HT29-mock cells was immunoprecipitated using anti-Cdk3, and the binding with c-Jun was visualized by Western-blotting. C. c-Jun in HT29-Cdk3 or HT29-mock cells was immunoprecipitated using c-Jun antibody. Cdk3 and c-Jun proteins were visualized by Westernblotting analysis. D. Cdk3 co-localizes and binds to c-Jun ex vivo. HT29-Cdk3 and HT29-mock cells were fixed with paraformaldehyde, stained for Cdk3 (green) and c-Jun (red), and then visualized by immunofluorescence microscopy. The localization and binding of Cdk3 and c-Jun are indicated. Original magnification, $\times 1000$. Scale bar, $50 \mu \mathrm{m}$. IP: immunoprecipitation; WB: Western-blotting. 
compared with the group with c-Jun and Cdk3. These results show that Cdk3 phosphorylates c-Jun in ex vivo.

A persistent alteration in AP-1 activity can result in enhanced cancer cell metastasis [27, 28]. c-Jun is a major component of AP-1 [29], phosphorylated c-Jun plays an important role in AP-1 activation [24], and AP-1 activation mediated by c-Jun phosphorylation is involved in cell invasion [30, 31]. To confirm whether c-Jun phosphorylation mediated by $\mathrm{Cdk} 3$ is responsible for the AP-1 activation, we next transfected AP-1 luciferase reporter plasmid (pG2-AP-1-luc) into HT29-Cdk3, HT29-Cdk3-DN, and HT29-mock cells, AP-1 activity was detected using luciferase reporter assay. The results showed that AP-1 activity in Cdk3 stably-transfected cells with EGF treatment was higher than that without EGF (Figure 4C lanes $8 v s$. lane 9; $* P<0.05$ ), and EGF-induced AP-1 activation response in Cdk3 stablytransfected cells was much greater than the response of the Cdk3-DN stably-transfected cells (Figure 4C, lane 6 vs. lane 9 ; $* P<0.05$ ). Without EGF treatment, AP-1 activity was also higher in $\mathrm{Cdk} 3$ transfect than that in the mock and Cdk3-DN (Figure 4C, lanes 2, 5 vs. lane 8; $* P<$ $0.05)$. Overall, these results imply that $\mathrm{Cdk} 3$ is responsible for AP-1 activation.

\section{Cdk3 promotes colon cancer metastasis ex vivo}

Cdk3-medaited metastasis was confirmed in nude mice, Cdk3 stable-express cell line, HT29-Cdk3 cell line was used in this study. HT29-Cdk3 cells were mixed with Matrigel, and then injected into the tail veins of $\mathrm{BABL} / \mathrm{c}$ nude mice, HT29-mock served as the control. After 60 days, these mice were sacrificed, and the lung, liver and lymph nodes were observed. To compare with the mock, metastasis of HT29-Cdk3 to the lung and liver significantly increased (Figure 5A), the metastasis to lymph nodes was not observed. The weight of metastatic tumors was increased in HT29-Cdk3 when compared with the mock (Figure 5B, $P<0.05$ ). Under microscopy, the metastatic foci in the liver and lung were bigger in HT29Cdk3 than that in the mock (Figure 5C). These results indicate that $\mathrm{Cdk} 3$ enhances colorectal cancer metastasis.

\section{Exogenous expression of Cdk3 induces EMT-like cellular marker alteration in colorectal cancer cells}

The above results showed that $\mathrm{Cdk} 3$ can promote migratory/invasive properties of colorectal cancer. Since the enhanced migratory/invasive ability of epithelial cells is often caused by EMT, we analyzed a panel of representative epithelial and mesenchymal markers to determine whether this process occurs in Cdk3 mediating colorectal cancer metastasis. The results showed that Cdk3 ectopic expression caused an EMT-like marker shift, including downregulation of epithelial markers E-cadherin (Figure 6A-a) and $\alpha$-catenin (Figure 6A-c), and upregulation of mesenchymal markers fibronectin (Figure 6A-e) and EMT-associated transcription factor snail (Figure 6A-i), vimentin (Figure 6A-g). Western-blotting analysis further revealed that E-cadherin (Figure $6 \mathrm{~B}, 2^{\text {nd }}$ panel) and $\alpha$-catenin (Figure $6 \mathrm{~B}, 3^{\text {rd }}$ panel) expression dramatically decreased (Figure 6B), while the levels of fibronectin (Figure $6 \mathrm{~B}, 4^{\text {th }}$ panel), vimentin (Figure $6 \mathrm{~B}$, $5^{\text {th }}$ panel) and snail (Figure $6 \mathrm{~B}, 6^{\text {th }}$ panel) increased in Cdk3-expressing cells. Simultaneously, AP-1 activity was detected in HT29-Cdk3 and HT29-mock cells. The data showed that AP-1 activity was significantly higher in HT29-Cdk3 than in HT-mock (Figure 6C, lane 4 vs. $5, * P<0.05)$. These results thus demonstrated that Cdk3 induces EMT-like molecular alterations with AP-1 activation in colorectal cancer.

To further investigate whether endogenous Cdk3 contributes to EMT phenomenon, we observed whether colorectal cancer cells lacking endogenous $\mathrm{Cdk} 3$ expression demonstrate any EMT-like cellular marker reversal. Following Cdk3 knockdown in SW620 cells (Figure 6D), we found that Cdk3 knockdown caused a mesenchymal to epithelial shift, including E-cadherin (Figure 6D-a) and $\alpha$-catenin (Figure 6D-c) upregulation, and fibronectin (Figure 6D-e), snail (Figure 6D-g) and vimentin (Figure 6D-i) downregulation. Similarly, we also found by western-blotting that the expression of $\mathrm{E}$-cadherin (Figure $6 \mathrm{E}, 2^{\text {nd }}$ panel) and $\alpha$-catenin (Figure $6 \mathrm{E}, 3^{\text {rd }}$ panel) were increased, whereas vimentin (Figure $6 \mathrm{E}, 4^{\text {th }}$ panel), fibronectin (Figure $6 \mathrm{E}, 5^{\text {th }}$ panel), snail and vimentin (Figure $6 \mathrm{E}, 6^{\text {th }}$ panel) were decreased in SW620-siCdk3 cells. Simultaneously, AP-1 activity was significantly low in SW620-siCdk3 in comparison with SW620-simock (Figure 6F, lane 4 vs. 5, $* P<0.05$ ). To further confirm whether the activated AP- 1 by Cdk3 participates in EMT shift, AP-1 activity was inhibited with curcumin in HT29-Cdk3 cells, and then EMT shift markers were detected. After curcumin treatment, E-cadherin and $\alpha$-catenin were increased (Figure 6G, right lane in $2^{\text {nd }}, 3^{\text {rd }}$ panels), and fibronectin, snail and vimentin were decreased (Figure $6 \mathrm{G}$, right lane in $4^{\text {th }}, 5^{\text {th }}, 6^{\text {th }}$ panels). The shift from epithelial to mesenchymal was blocked when AP-1 activity being inhibited. These results indicate that $\mathrm{Cdk} 3$ activating AP-1 plays an important role in EMTlike marker shift.

\section{Cdk3 induces EMT-like cellular marker alteration in metastatic tumors of nude mice}

The above results showed that $\mathrm{Cdk} 3$ induces the EMT shift of colorectal cancer cell in vitro. To further confirm whether Cdk3-mediated EMT is involved in colorectal cancer metastasis ex vivo, the metastatic tumor samples of nude mice were used to test EMT-like marker 
A
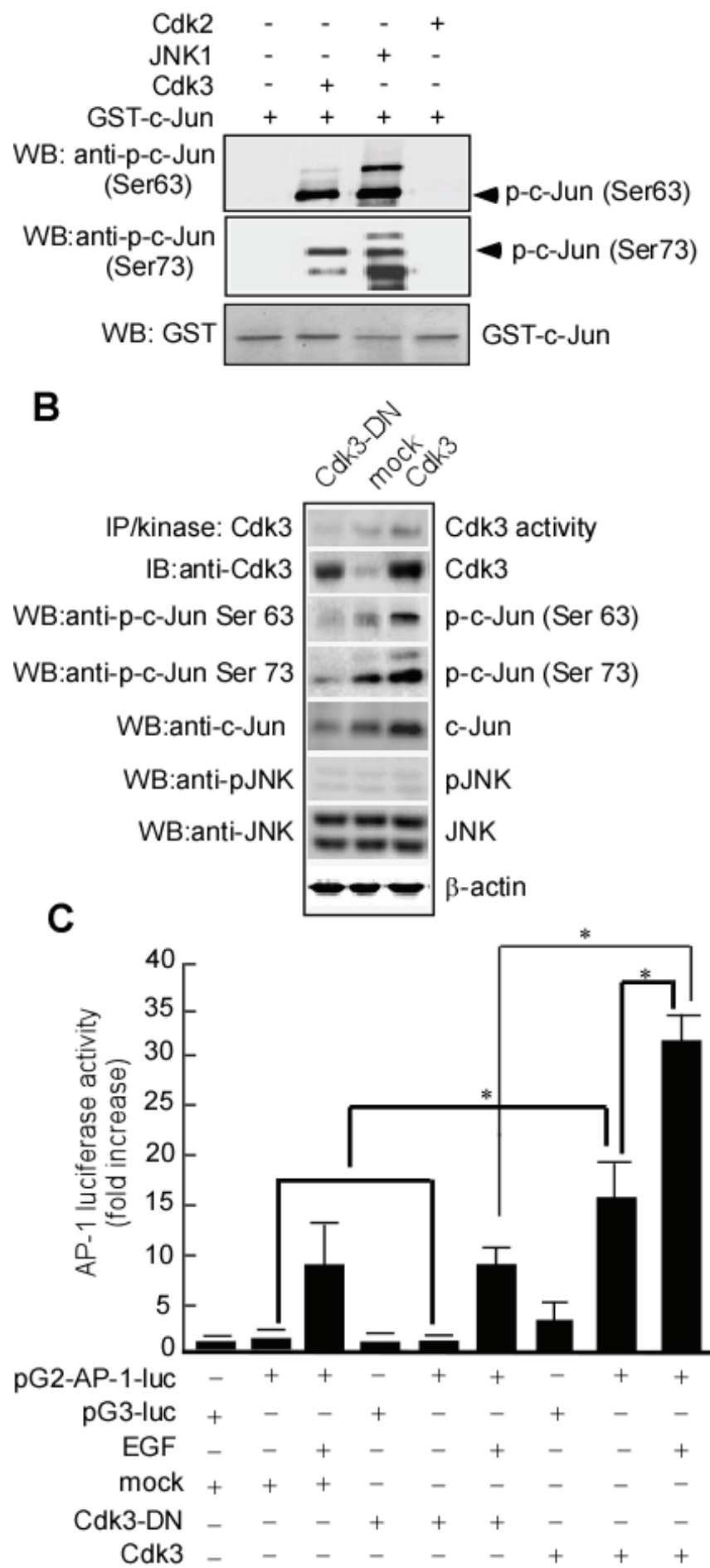

Figure 4: Cdk3 activates AP-1 through phosphorylating c-Jun. A. In vitro kinase assay of Cdk3 to c-Jun. GST-c-Jun protein served as substrate for active Cdk3. Reactive products were subjected to Western-blotting using phosphorylation antibody against c-Jun Ser 63 or Ser 73. GST with Western-blotting staining served as a loading control. The reaction of GST-c-Jun and active JNK1 served as a positive control. B. pRcCMV-HA-Cdk3 and pHis6-tagged c-Jun plasmids were transiently transfected into HEK293 cells. Cdk3 activity was detected using immunoprecipitation and in vitro kinase assay. Cdk3, c-Jun, phosphorylated c-Jun at Ser 63 or 73, JNK, and phosphorylated-JNK expressions were detected by Western-blotting. $\beta$-actin served as the loading control. C. HT29-Cdk3, HT29-Cdk3-DN and HT29-mock cells were transfected with the pG2-AP-luciferase promoter (pG2-AP-1-luc). The cells transfected with the pG3-luciferase promoter (pG3-luc) serviced as vector control. Luciferase activity in the transfected cell was measured using the Luminoskan Ascent plate reader. Three individual experiments and presented as mean $\pm \mathrm{SD}$. *, represented $P<0.05$. IP, immunoprecipitation. WB, Western-blotting. p-c-Jun, phosphorylated c-Jun. 
expression. The immunohistochemistry staining revealed that the metastatic tissues of HT29-Cdk3 displayed E-cadherin (Figure 7-b) and $\alpha$-catenin (Figure 7-d) downregulation, and fibronectin (Figure 7-f), vimentin (Figure 7-h) and snail (Figure 7-j) upregulation. This result consists with the above vitro data.

\section{DISCUSSION}

$\mathrm{Cdk} 3$ functions in the regulation of G1-S cell cycle translation [17], it participates in G1-S progression by binding E2F1,E2F2, or E2F3. Recently, Cdk3 was found a novel function, which is involved in cancer development and progression. Cdk3 is overexpressed in a number of
A
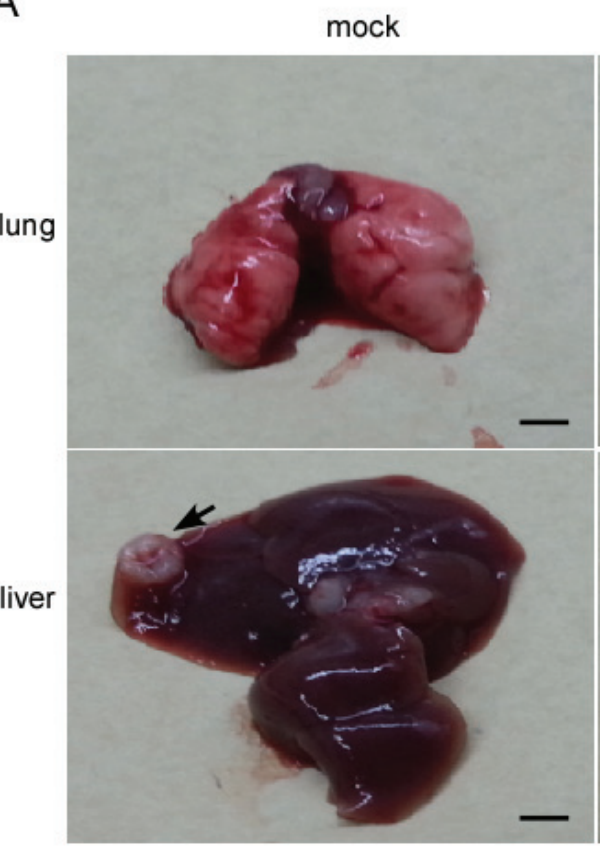

C

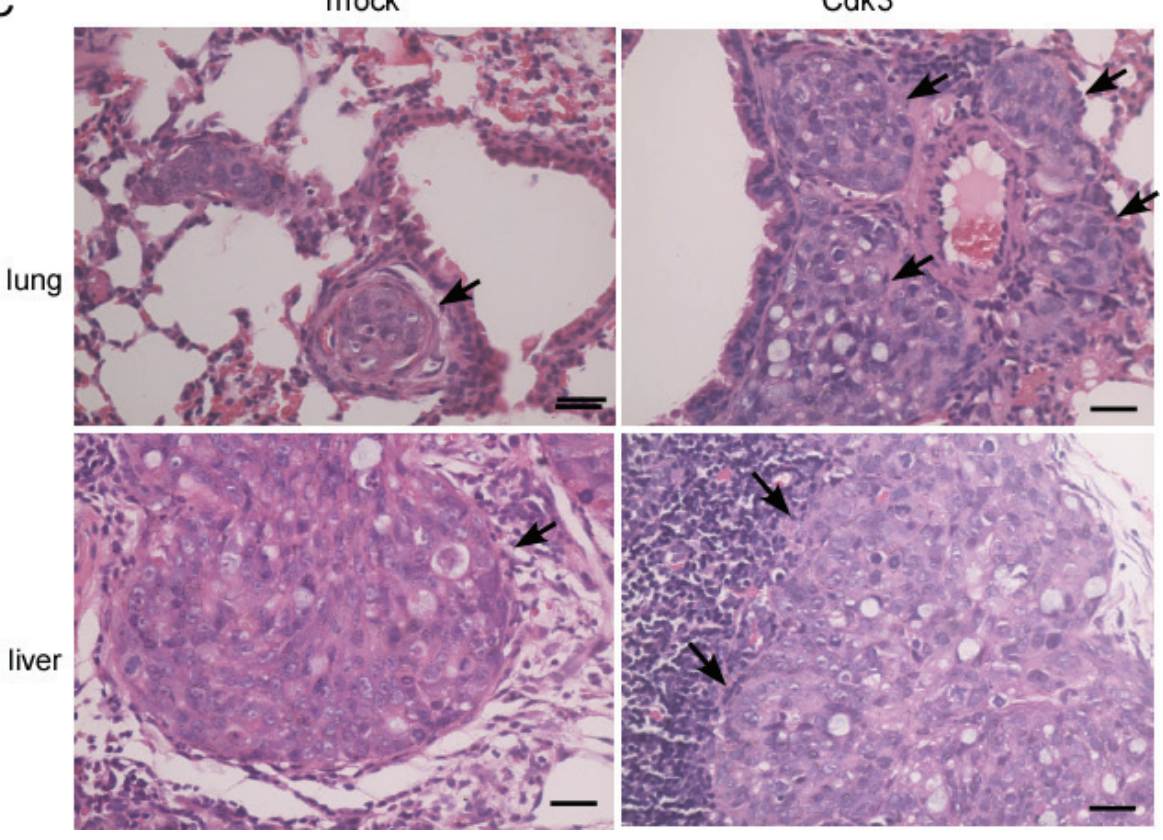

B
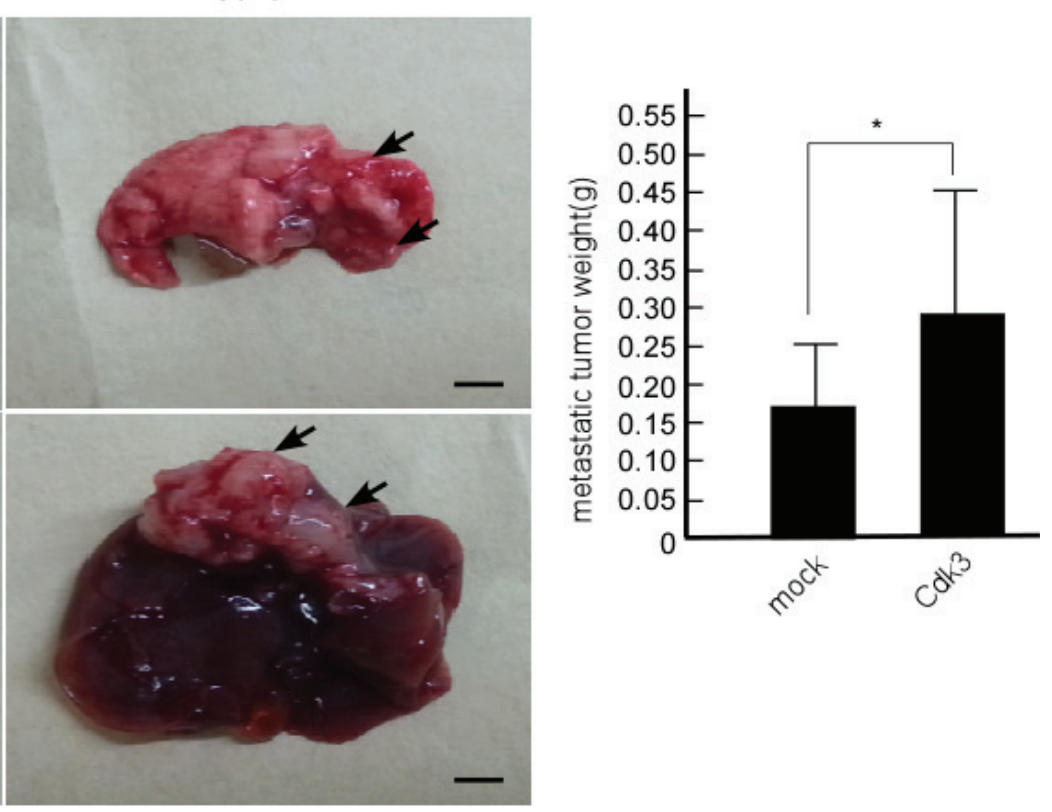

Figure 5: Cdk3 enhances the metastasis of colorectal cancer cell ex vivo. A. 20 nude mice were randomly divided into two groups with 10 mice per group. One group was injected with HT29-Cdk3 cells in Matrigel through the tail vein, and the other group was injected with HT29-mock. After 60 days, the nude mice were sacrificed, and the metastatic tumors were observed. Arrows, metastatic node. B. the metastatic tumors from the lung and live were weighed. Scale bar $=0.5 \mathrm{~cm}\left({ }^{*}, p<0.05\right)$. C. The metastatic tumors were subjected to paraffin embedding and section. Paraffin sections of the metastatic tumors were stained with hematoxylin and eosin. Arrows, metastatic foci. Original magnification, $\times 400$. Scale bar $=20 \mu \mathrm{m} .{ }^{*}$, represented $P<0.05$. 


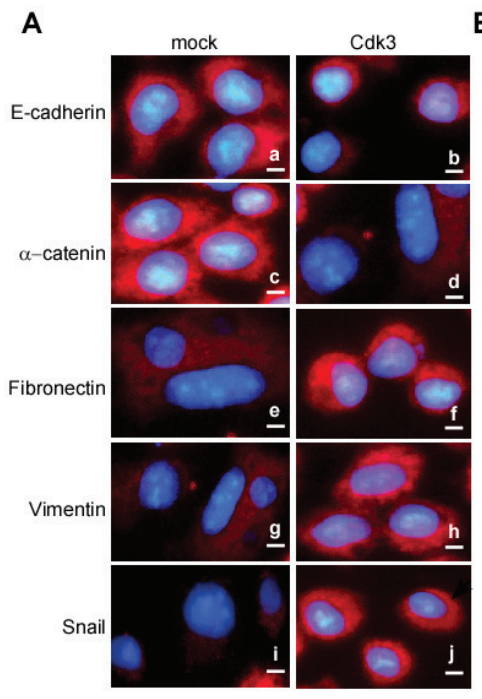

B
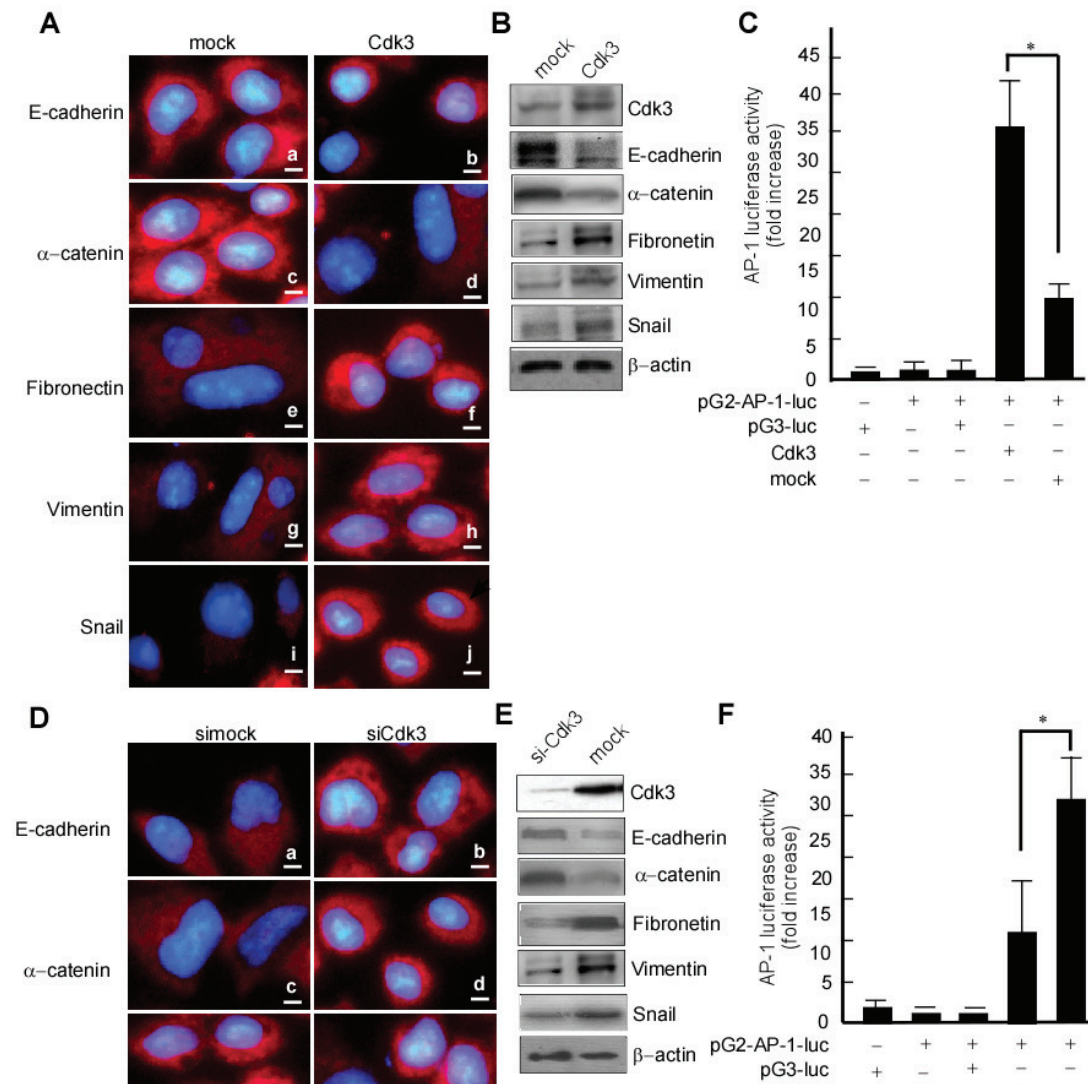

$\mathbf{F}$
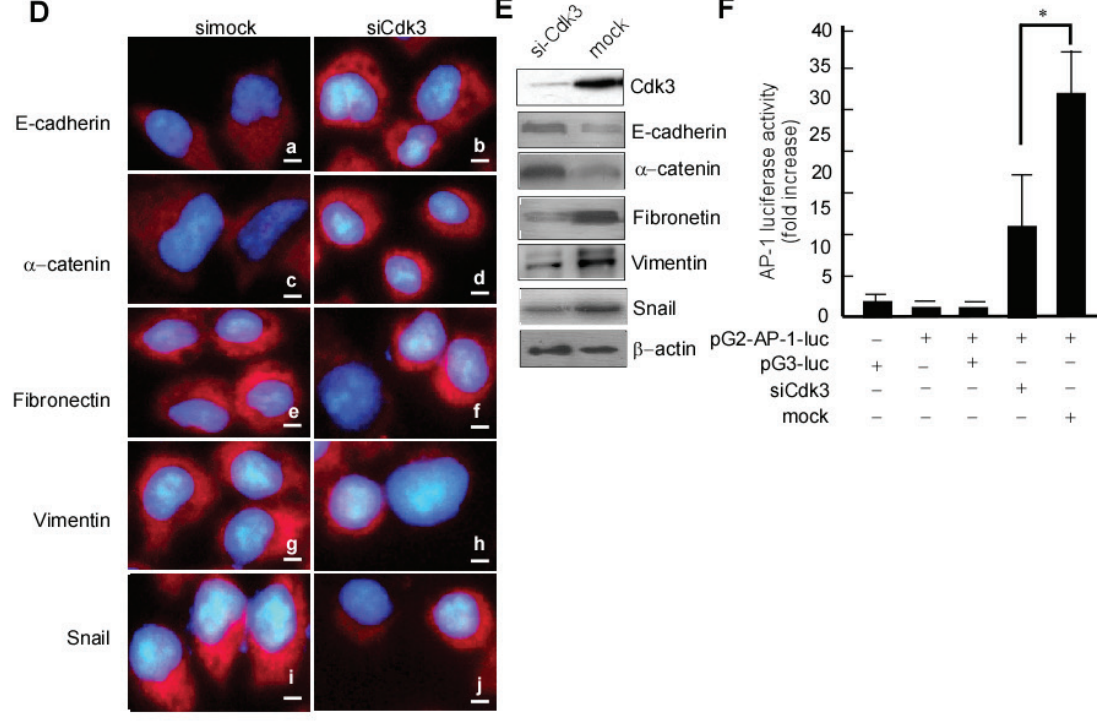

G
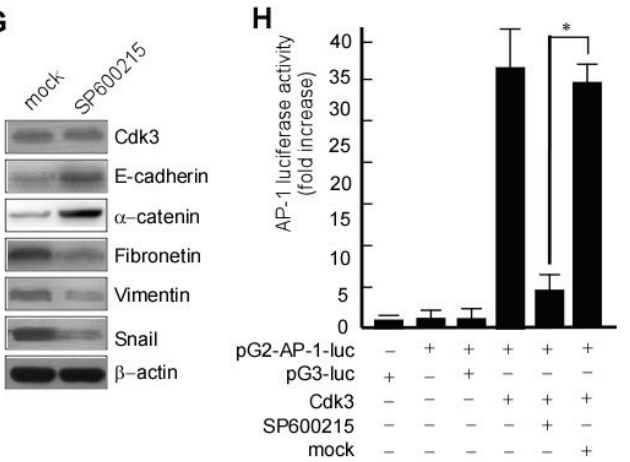

Figure 6: Cdk3 induces EMT-like cellular marker alterations. HT29-Cdk3 and HT29-mock cells were used to detect the expression of EMT markers. A. E-cadherin (a, b), $\alpha$-catenin (c, d), fibronectin (e, f), vimentin (g, h), and snail (I, j) were detected in HT29Cdk3 and HT29-mock cells using immunofluorescence. Magnification, $\times 1000$, scale bar $=50 \mu \mathrm{m}$. B. E-cadherin, $\alpha$-catenin, fibronectin, vimentin, and snail were detected in HT29-Cdk3 and HT29-mock cells using Western-blotting. C. AP-1 activity was detected in HT29Cdk3 and HT29-mock cells as described in Materials and Methods. Three individual experiments and presented as mean \pm SD. D. SW620siCdk3 and SW620-simock cells were used to detect the expression of EMT markers. E-cadherin (a, b), $\alpha$-catenin (c, d), fibronectin (e, f), vimentin (g, h), and snail (I, j) were detected in SW620-siCdk3 or SW620-simock cells using immunofluorescence. Magnification, $\times 1000$, scale bar $=50 \mu \mathrm{m}$. E. E-cadherin, $\alpha$-catenin, fibronectin, vimentin, and snail in SW620-siCdk3 and SW620-simock cells were detected using Western-blotting. F. AP-1 activity was detected in SW620-siCdk3 and SW620-simock cells as described in Materials and Methods. HT29-Cdk3 cells were treated with curcumin, and E-cadherin, $\alpha$-catenin, fibronectin, vimentin, and snail were detected using Westernblotting $(\mathrm{G}), \mathrm{AP}-1$ activity was detected using luciferase activity assay $(\mathrm{H})$. Three individual experiments and presented as mean $\pm \mathrm{SD}$. *, represented $P<0.05$. 
cancer tissues and cancer cell lines [21, 32, 33], and it has been found to be deregulated or mutated in numerous human tumors. Cdk3 is activated by DNA tumor virus proteins EIA, SV40 large T, and E7 through binding to $\mathrm{pRb}$ and consequent release of E2F [34]. Herpes simplex virus (HSV) can also activate Cdk3 [35]. Experimental studies showed that $\mathrm{Cdk} 3$ promotes cell transformation $[15,23,24,36]$. Clinical investigations showed that Cdk3 highly expresses in various tumor [20-22], and its expression was associated with the degree of infiltration, lymph node metastasis and clinical staging [21, 22]. Ouelaa-Benslama $\mathrm{R}$ et al. reported that $\mathrm{Cdk} 3$ participates in EMT shift mediated by G $\alpha \mathrm{G} \beta \gamma$, AKT and PKC $\alpha$ [37]. Based on these, we speculated that $\mathrm{Cdk} 3$ may be involved in cancer metastasis. To confirm this speculation, we at first detected $\mathrm{Cdk} 3$ protein expression and activity in the biopsy tissues of colorectal cancer, and found that both Cdk3 expression and activity are high in metastatic tissues. Further, Cdk3 expression-vector was used to investigate its effect in cancer metastasis, we found that $\mathrm{Cdk} 3$ can promote the motility and invasion of colorectal cancer cell in vitro and metastasis ex vivo, mediate cell EMT shift. We think that Cdk3 is involved in not only cancer development but also metastasis.

To further analyze the mechanism of $\mathrm{Cdk} 3$-mediated metastasis, based on the previous finding, $\mathrm{Cdk} 3$ activating AP-1 through phosphorylating c-Jun, we investigated whether Cdk3-activating AP-1 participates in colorectal cancer metastasis. Our results showed that Cdk3 could phosphorylate c-Jun in vitro or ex vivo, and activate AP-1, increase cell motility and invasion. It is reported that as a major component of AP-1 [29], c-Jun phosphorylation plays an important role in AP-1 activation [24], and AP-1 activation though c-Jun phosphorylation participates in cell invasion [30, 31]. Cdk3 may directly be an upstream of c-Jun, and our data indicated that Cdk3 was a kinase involved in the signaling induced by EGF treatment. Phosphorylation of c-Jun at Ser63 and Ser73 mediates
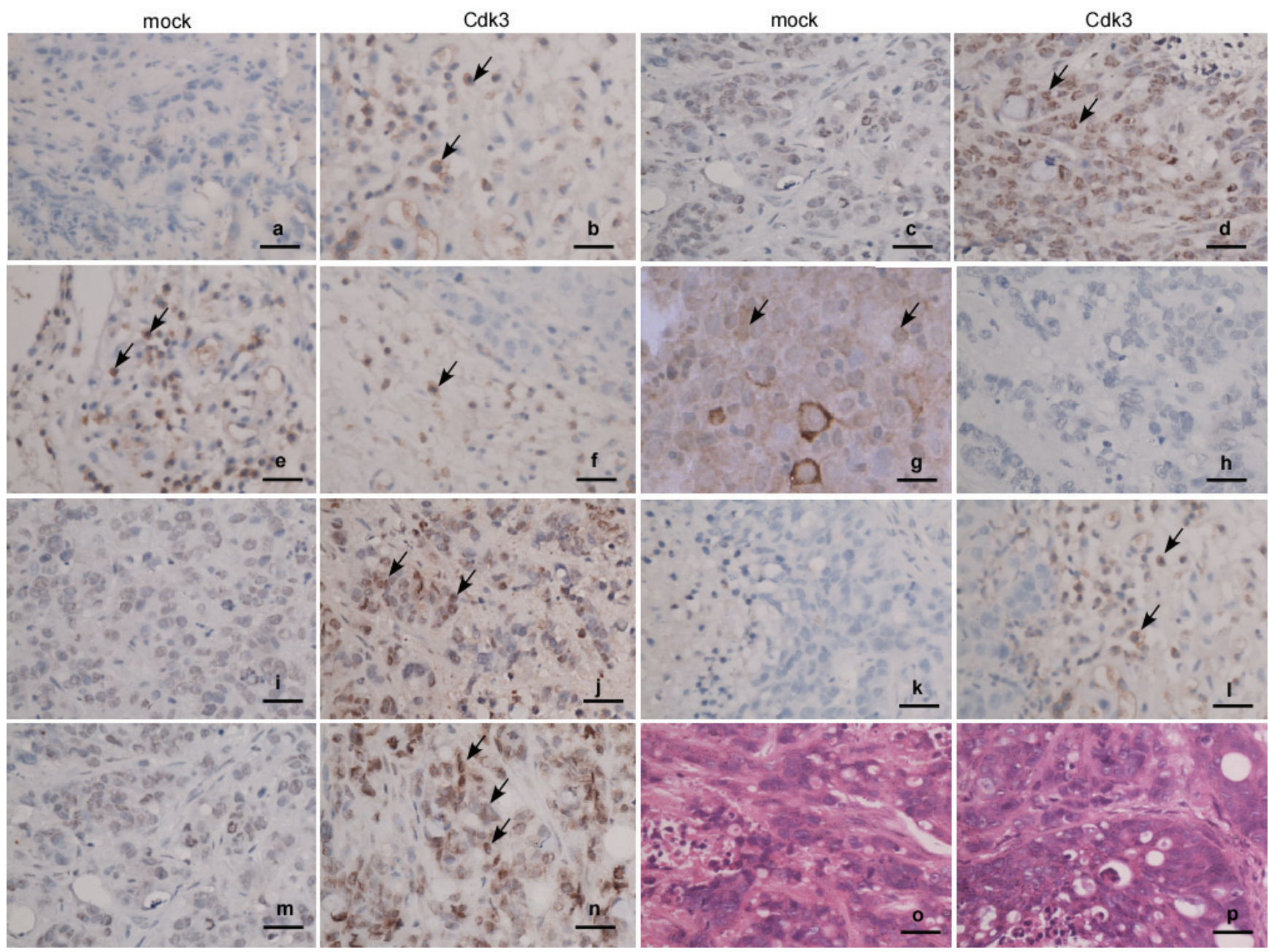

Figure 7: Expression of EMT markers in Cdk3-promoted metastatic tumors. The metastatic tumors were subjected to paraffin embedding and section. Expressions of Cdk3, c-Jun, E-cadherin, $\alpha$-catenin, vimentin, fibronectin and snail in the metastatic tumors were detected using immunohistochemistry assay. Paraffin sections were stained with antibody against Cdk3 (a, b), c-Jun (c, d), E-cadherin (e, f), $\alpha$-catenin $(g, h)$, fibronectin $(i, j)$, vimentin $(k, 1)$ or snail $(m, n)$, and also stained with hematoxylin and eosin (o, p). Arrows, positive cells. Magnification, $\times 40$, scale bar $=10 \mu \mathrm{m}$. 
the transactivation function of c-Jun, which is required for its function as an oncoprotein. AP-1 activation occurs in various cancer [38] and plays an important role in cancer development and progression [39]. Based on the above, we think that Cdk3 increases AP-1 activity through c-Jun phosphorylation and promotes colorectal cancer metastasis.

Hepatic metastasis is the most common form of distant spread of primary colorectal cancer. It is estimated that approximately $50 \%$ of patients with colorectal cancer develop hepatic metastases synchronously or metachronously, and in advanced disease the mortality of colorectal cancer is principally attributable to the development of hepatic metastases [1]. In this study, animal experiments showed that $\mathrm{Cdk} 3$-induced metastasis was observed in the livers and lungs of nude mice, and mainly existed in the livers, this consists with Jemal A's reports [1]. The results suggested that $\mathrm{Cdk} 3$ plays an important role in hepatic metastases of colorectal cancer.

FoxM1 overexpression is significantly associated with colon cancer metastasis. FoxM1-mediated colon cancer metastasis is linked to regulating E-cadherin, vimentin, Snail expressions [13]. As a transcription factor of S100P, SOX9 binds to and activates S100P promoter,

\section{Cdk34}
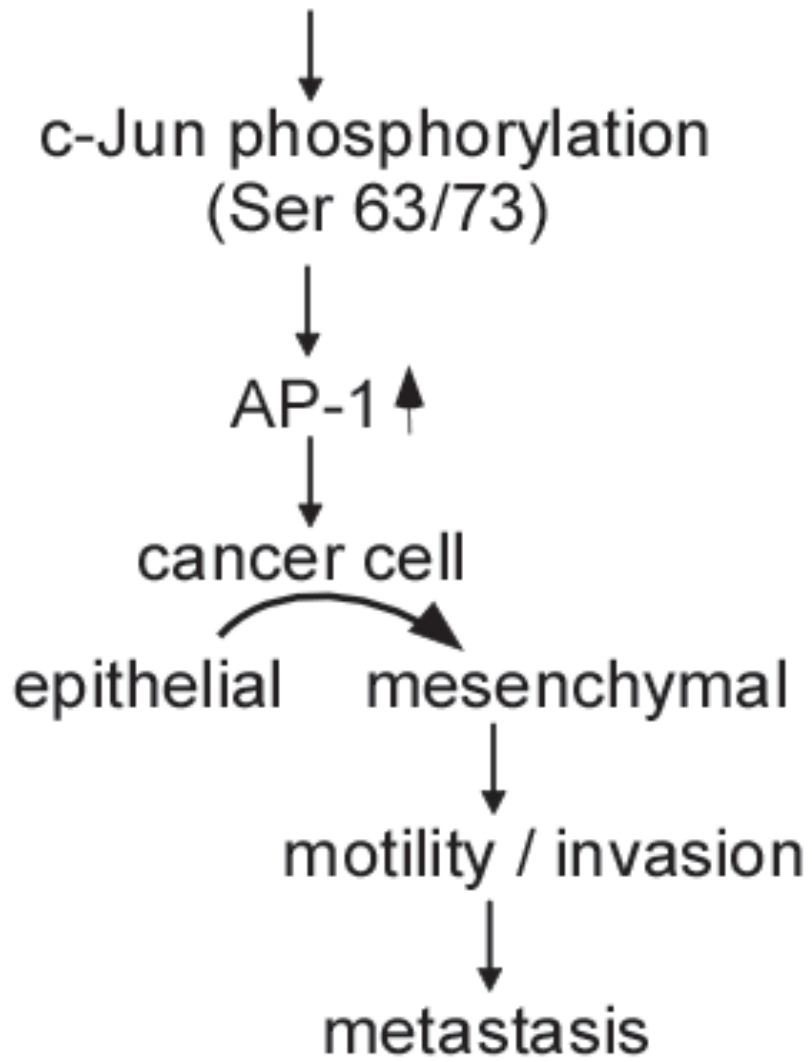

Figure 8: Schematic illustration of Cdk3-mediating colorectal cancer metastasis. $\mathrm{Cdk} 3$ activates $\mathrm{AP}-1$ through phosphorylating c-Jun Ser 63/73, mediates EMT alteration, increases motility and invasion, and promotes colorectal metastasis. and induces invasiveness and metastasis of colon cancer cells. The decreased expression of SOX9 dramatically inhibits the tumor growth and peritoneal metastasis in nude mice. Furthermore, SOX9 regulates E-cadherin, $\mathrm{N}$-cadherin, vimentin and Snail expressions at protein and mRNA levels, mediates EMT, promotes colon cancer metastasis [14]. We think that Cdk3 may also promote colorectal cancer metastasis through regulating EMT shift. The three reasons are illustrated as follows. The first one is that ectopic expressed Cdk3 caused an EMT-like marker shift, including a dramatic downregulation of the epithelial markers E-cadherin and $\alpha$-catenin, and upregulation of the mesenchymal markers fibronectin and the EMT-associated transcription factor snail and vimentin. The second is that Cdk3 activated AP-1 through induction of c-Jun Ser 63/73 phosphorylation, AP-1 activation promoted cancer cell from epithelial to mesenchymal transition $[25,26]$. And the third one is that EMT marker alternation existed in Cdk3-mediated metastatic tumor ex vivo. Taken together, our data indicated that $\mathrm{Cdk} 3$ activates AP-1through phosphorylating c-Jun Ser 63/73, induces EMT alteration, increases motility and invasion of colorectal cancer, and finally promotes colorectal cancer invasion and migration (Figure 8).

\section{MATERIALS AND METHODS}

\section{Ethics statement}

All animal works were conducted under the institutional guidelines of Hunan Province and approved by the Use Committee for Animal Care. Approval from the Zhuhai Hospital of Jinan University Ethics Committee and Xiangya Hopital of Central South University Ethics Committee was obtained, and written informed consent was provided by each human subject.

\section{Reagents and antibodies}

Reagents including Tris, $\mathrm{HCl}$, EDTA, $\mathrm{KCl}, \mathrm{NaCl}$, and SDS for buffer preparation, and curcumin were purchased from Sigma-Aldrich (St. Louis, MO). Cell culture medium and other supplements were obtained from Life Technologies (Rockville, MD). Cdk3 active kinase was purchased from Upstate Biotechnology, Inc. (Lake Placid, NY). Antibodies against Cdk3, E-cadherin, $\alpha$-catenin, fibronectin, snail, and vimentin were from Santa Cruz Biotechnology, Inc. (Santa Cruz, CA) and Cell Signal Technology, Inc. (Beverly, MA). Taq DNA polymerase was purchased from Qiagen, Inc. (Valencia, CA). The jetPEI was purchased from Qbiogen, Inc. (Montreal, Quebec, Canada). G418 was from Biomol International, L.P. (Plymouth Meeting, PA). Matrigel was purchased from Collaborattiv Biomedical Products (Bedford, MA). 
Boden chamber was purchased from Neuro Probe (Cabin John, MD)

\section{Colon cancer sample}

188 tissue specimens including 52 cases of normal colon tissues (NCE), 87 cases of primary colon cancer (PCC), and 49 cases of metastatic colon cancer (MCC) were obtained from Xiangya Hospital from Jan, 2007 to Sep, 2011. Every specimen was fixed with $40 \mathrm{~g} / \mathrm{L}$ paraformaldehyde solution, followed by dehydration and paraffin embedment. $4 \mu \mathrm{m}$ serial sections were utilized for immunohistochemistry. Additionally, for Cdk3 activity assay, the fresh tissues samples of 21 cases NCE, 27 cases PCC, and 24 cases MCC were obtained by surgical operation. All patients had only one primer tumor, and no one had received another treatment.

\section{Cell culture and treatments}

HEK293, HT29, SW620, HCT116, SW480 and HCoEpiC (human colonic epithelia cell) were from Cell Center of Central South University (Changsha, CN). These cell lines were cultured with 1640 medium supplemented with $10 \%$ fetal bovine serum (FBS) and antibiotics at $37^{\circ} \mathrm{C}$ in a $5 \% \mathrm{CO} 2$ incubator. Colorectal cancer cell lines, HT29 and SW480 have a low metastatic ability, SW620 and HCT116 have high ability [40]. The cells were maintained by splitting at $90 \%$ confluence and media were changed every 3 days. For transfection experiments, cells at 50 to $60 \%$ confluence were transfected using jetPEI (Qbiogen, Inc.) following the manufacturer's suggested protocol. HCoEpiC cells were transfected with pRcCMVHA-Cdk3 and pHis6-tagged c-Jun for determine the binding of Cdk3 and c-Jun. HT29 cells were transfected with pRcCMV-HA-Cdk3 or pRcCMV-HA (mock). Cdk3 stably-transfected cell line and mock cell were obtained by selection for G418 resistance ( $400 \mu \mathrm{g} / \mathrm{ml})$, and further confirmed by assessing Cdk3 activity and expression [41]. For Cdk3 rescue experiments, SW620-siCdk3 cells were transiently transfected with pRcCMV-HA-Cdk3, and then used for motility and invasion assay, and $\mathrm{Cdk} 3$ expression and activity assay. TH29-Cdk3 cells were treated with curcumin at $10 \mu \mathrm{M}$ for 30 min for motility and invasion assay. The treated cells were used to detect E-cadherin, $\alpha$-catenin, fibronectin, vimentin and snail expression, and these treated cells were also used for AP-1 activity assay [42].

\section{Immunohistochemistry}

Immunohistochemistry was done on the formalinfixed and paraffin-embedded tissue sections using a standard immunohistochemical technique. $4 \mu \mathrm{m}$ thick tissue sections were deparaffinized in xylene, rehydrated in a graded alcohol series, and treated with an antigen retrieval solution $(10 \mathrm{mmol} / \mathrm{L}$ sodium citrate buffer, $\mathrm{pH}$ 6.0) [43]. The sections were incubated with anti-Cdk3, c-Jun, E-cadherin, $\alpha$-catenin, fibronectin, vimentin or snail antibody (Abcam, dilution 1:50) overnight at 4 ${ }^{\circ} \mathrm{C}$. Subsequently, the sections were incubated with a biotinylated secondary antibody (Zhongshan Inc., China), followed by incubation with an avidin-biotin complex (Zhongshan Inc., China) according to the manufacturer's instructions. Finally, tissue sections were incubated with 3',3'-diaminobenzidine (DAB) (Sigma-Aldrich) and hydrogen peroxide for $2 \mathrm{~min}$, and counterstained with haematoxylin for $30 \mathrm{~s}$. In negative controls, primary antibodies were omitted.

\section{Evaluation of Cdk3 staining}

Sections were blindly evaluated by two investigators in an effort to provide a consensus on staining patterns under light microscopy (Olympus). Cdk3 staining was assessed according to the methods described by Cheng AL [44] and Li YJ [45] with minor modifications. Each case was rated according to a score that added a scale of intensity of staining to the area of staining. At least 10 high-power fields were chosen randomly, and $>1000$ cells were counted for each section. The depth of staining was graded on the following scale: 0 , no cell coloration; $1+$, light yellow; $2+$, brown; $3+$, tan. The area of staining was evaluated as follows: 0 , no staining of cells in any microscopic fields; $1+,<30 \%$ of tissue stained positive; $2+$, between $30 \%$ and $60 \%$ stained positive; $3+,>60 \%$ stained positive. The summed (extension + intensity) was used as the total score, where $0-1$ indicates a negative score (-); $\geq 2$ a positive score $(+)$ [45]. The correlation of CDK3 expression with clinical features and prognosis of colorectal cancer patients was analyzed. Statistical analysis was done using SPSS (version 18.0), a difference of $\mathrm{P}<0.05$ was considered statistically significant.

\section{Cell motility and invasion assay}

For cell invasion assay, the treated cells were removed by trypsinization, and their invasiveness was tested by the Boden chamber invasion assay in vitro [46]. Matrigel (Collaborattiv Biomedical Products, Bedford, MA) was diluted to $25 \mathrm{mg} / 50 \mathrm{ml}$ with cold filtered distilled water and applied to $8 \mathrm{~mm}$ pore size polycarbonate membrane filters. The cells were seeded to Boden chamber (Neuro Probe, cabin John, MD) at the upper part at a density of $1.5 \times 10^{4}$ cells/well in $50 \mu \mathrm{l}$ of serum-free-medium, and then incubated for $12 \mathrm{~h}$ at 37 ${ }^{\circ} \mathrm{C}$. The bottom chamber also contained standard medium with $20 \%$ fetal bovine serum (FBS). The cells invaded to lower surface of membrane were fixed with methanol 
and stained with hematoxylin and eosin. Random field was counted for invaded cells under a light microscope. To determine cell motility, the cells were seed into Boyden Champer on membrane filters, which not coated with Matrigel. Migration of cells was measured as described in the motility assay [46]. Statistical analysis was corrected with cell viability to clarify the effect of $\mathrm{Cdk} 3$

\section{Construction of expression vectors}

pRcCMV-HA-Cdk3, pRcCMV-HA were gifts from Dr. Barrett J. Rollins (Harvard Medical School, Boston, Massachusetts) [17]. pU6pro vector was provided by David L. Turner (University of Michigan, Ann Arbor, MI). pU6pro was used to construct pU6pro-simock (simock) and Pu6pro-siCdk3 (siCdk3) following the recommended protocol. For constructing the simock and siCdk3, we synthesized primers for simock (general scramble: sense TTCAAGAGACACCTATAACAACGGTAGTTTTTT-3', and antisense ACTACCGTTGTTATAGGTGTCTCTTGAACACCTAT AACAACGGTAGT-3'). siCdk3 was synthesized using primers (sense 5'-TTTGTGAGTTGGG TGCCATCAAGTTCAAGAGACTTGATG

GCACCCAACTCATTTTT-3', and antisense AAAATGAGTTGGGTGCCATCAAGTCTCTTGAACTT GATGGCACCCAACTCA-3'). All constructs were confirmed by restriction enzyme mapping and DNA sequencing [24]. AP-1 luciferase reporter plasmid contains the -73 to +63 collagenase promoter sequence [47]. CMVneo marker vector plasmid was constructed as previously reported [47, 48]. pHis6-tagged c-Jun was kindly provided by Dr. Dirk Bohmann (European Molecular Biology Laboratory, Heidelberg, Germany) [49]. c-Jun fragment was generated by PCR and subcloned into the pGEX$5 \mathrm{x}-1$ vector (Amersham Biosciences Corp., Piscataway, $\mathrm{NJ})$ at the BamHI/Xhol site to generate a glutathione S-transferase (GST)-c-Jun plasmid (pGST-c-Jun) [47, 50].

\section{Western-blotting}

Equal numbers $\left(1.0 \times 10^{6}\right)$ of the treated cells were harvested, and washed once with ice-cold phosphatebuffered saline (PBS). The cell samples were disrupted with $0.6 \mathrm{ml}$ RIPA buffer $(1 \times$ PBS, $1 \%$ Nonidet P-40, 0.5\% sodium deoxycholate, $0.1 \%$ SDS, and freshly added 100 $\mu \mathrm{g} / \mathrm{ml}$ phenylmethanesulfonyl fluoride, $10 \mu \mathrm{g} / \mathrm{ml}$ aprotinin, $1 \mathrm{mM}$ sodium orthovanadate). The cell lysates were clarified by microcentrifuge and the supernatant fractions were saved to perform next steps. The concentration of supernatant fractions was determined using the Bio-Rad Protein Assay (Bio-Rad Laboratories, Inc., Hercules, CA). The samples containing equal amounts of protein in an equal volume of RIPA buffer were diluted with $5 \times$ SDS sample buffer [187.5 mM Tris- $\mathrm{HCl}$ pH 6.8, 6\% (w/v) SDS, 30\% (v/v) glycerol $150 \mathrm{mM}$ dithiothreitol (DTT) and $0.3 \%(\mathrm{w} / \mathrm{v})$ bromophenol blue]. Then samples were separated by $10 \%$ SDS-PAGE, and proteins were transferred on Nitrocellulose membrane [51, 52]. The membrane was subsequently incubated with $5 \%$ non-fat milk in PBS for $1 \mathrm{~h}$ to block non-specific binding, and incubated with specific antibody for $2 \mathrm{~h}$, and then with an appreciate peroxidase-conjugated secondary antibody for $1 \mathrm{~h}$. All incubations were carried out at $37^{\circ} \mathrm{C}$, and intensive PBS washing was performed each incubation. After 3 times PBS washing, signal was developed by 4-chloro-1-napthol/3,3-o-diamino-benzidine, and relative photographic density was quantitated by a gel documentation and analysis system. $\beta$-actin was used as an internal control to verify basal level expression and equal protein loading. Abundance ratio to $\beta$-actin was counted.

\section{Cdk3 immunoprecipitation kinase assay}

For Cdk3 activity assay of tissue samples, eightmicrometer-thick frozen sections of fresh NCE, PCC, and MCC were prepared using a Leica CM 1900 cryostat (Leica) at $-25^{\circ} \mathrm{C}$. The sections were placed on a membrane-coated glass slides $(2.0 \mu \mathrm{m}, 50$ pieces, PEF Membrane; Leica), fixed in 75\% alcohol for $30 \mathrm{~s}$, and stained with $0.5 \%$ violet-free methyl green (Sigma). The pooled microdissected cells from $21 \mathrm{NCE}, 27$ $\mathrm{PCC}$, or $24 \mathrm{MCC}$ specimens were used for vitro kinase assay. Each cell population was determined to be $95 \%$ homogeneous by microscopic visualization of the captured cells $[53,54]$. The microdissected cells were dissolved in kinase lysis buffer [25 mM Tris- $\mathrm{HCl}(\mathrm{pH} 7.5), 5 \mathrm{mM}$ $\beta$-glycerophosphate, $0.1 \mathrm{mM} \mathrm{Na} 3 \mathrm{VO} 4,10 \mathrm{mM} \mathrm{MgCl} 2$, $1 \mathrm{mM}$ aprotinin and $1 \mathrm{mM}$ PMSF] at $4^{\circ} \mathrm{C}$ for $1 \mathrm{~h}$, and then centrifuged. Protein concentration of the clarified supernatant fractions was measured. $100 \mu \mathrm{g}$ protein of the supernatant fraction was subjected to immunoprecipitation using Cdk3 antibody. The immune complexes were used to in vitro kinase assay. All solutions for staining were supplemented with protease inhibitor cocktail tablets (Roche Molecular Biochemicals).

For cell Cdk3 activity assay, the treated cells $\left(1.0 \times 10^{6}\right)$ were cultured for $12-24 \mathrm{~h}$ in $100-\mathrm{mm}$ dishes. After $70-80 \%$ confluence, the cells were washed once with ice-cold PBS, then harvested and disrupted in 250 $\mu l$ of kinase lysis buffer. The lysates were centrifuged. The protein concentration of supernatant fraction was measured. The supernatant fractions were subjected to immunoprecipitation using $\mathrm{Cdk} 3$ antibody. The immune complexes were used to in vitro kinase assay.

Cdk3 kinase assay of immunoprecipitation was carried out as described by the protocol from Upstate Biotechnology, Inc (Upstate Biotechnology, Inc., Lake Placid, NY). Briefly, the immune complex was added to $2.5 \mu \mathrm{l}$ of $10 \times$ kinase buffer $[250 \mathrm{mM}$ Tris- $\mathrm{HCl}(\mathrm{pH} 7.5)$, $50 \mathrm{mM} \beta$-glycerophosphate, $20 \mathrm{mM}$ DTT, $1 \mathrm{mM} \mathrm{Na} \mathrm{VO}_{4}$, 
$100 \mathrm{mM} \mathrm{MgCl} \mathrm{Mg}_{2}$, $2.5 \mu \mathrm{l}(2.5 \mu \mathrm{g})$ of GST-c-Jun protein, $10 \mu \mathrm{l}$ diluted ATP/cocktail (Upstate Biotechnology, Inc.), $10 \mathrm{Ci}$ of $\left[\gamma^{32}\right]$ ATP and $\mathrm{H}_{2} \mathrm{O}$ added to $25 \mu \mathrm{l}$. The reaction was incubated at $30^{\circ} \mathrm{C}$ for $30 \mathrm{~min}$ and then subjected to separation by $12 \%$ SDS-PAGE. c-Jun was analyzed by autoradiography as described $[52,55]$.

\section{In vitro kinase assay}

To determine phosphorylation of c-Jun by active $\mathrm{Cdk} 3$, a $\mathrm{Cdk} 3$ kinase assay was carried out at $30^{\circ} \mathrm{C}$ for $30 \mathrm{~min}$ in the presence of the kinase buffer $[25 \mathrm{mM}$ Tris$\mathrm{HCl}$ ( $\mathrm{pH}$ 7.5), $5 \mathrm{mM} \beta$-glycerophosphate, 2 mM DTT, 0.1 $\mathrm{mM} \mathrm{Na}_{3} \mathrm{VO}_{4}$, and $\left.10 \mathrm{mM} \mathrm{MgCl}_{2}\right]$ with $200 \mu \mathrm{M}$ ATP and $2 \mu \mathrm{g}$ of GST-c-Jun as substrate. The reaction solution was subjected to Western-blotting. The phosphorylation of c-Jun was analyzed by Western-blotting using antibody against c-Jun Ser63 or Ser73 as described [55].

\section{Immunofluorescence assay}

The treated cells $\left(1.0 \times 10^{3}\right)$ were seeded in eightchamber slides and incubated $24 \mathrm{~h}$ at $37^{\circ} \mathrm{C}, 5 \% \mathrm{CO}_{2}$, washed at each time point, fixed in $4 \%$ paraformaldehyde. The cells were hybridized with mouse monoclonal antibody against E-cadherin, $\alpha$-catenin, fibronectin, snail, vimentin or mouse at room temperature for $4 \mathrm{~h}$. After being washed, the cells were hybridized with anti-rabbit goat antibody conjugated with Texas Red or antibody against mouse conjugated with DAPAI for detection of cell nuclear. For determining co-localization of Cdk3 and c-Jun, HT29-Cdk3 and HT29-mock cells were hybridized with c-Jun mouse monoclonal antibody and Cdk3 rabbit monoclonal antibody for $4 \mathrm{~h}$. After the first hybridization, the cells were washed and then hybridized with antimouse goat antibody conjugated with Texas Red for c-Jun detection or anti-rabbit goat antibody conjugated with FITC for Cdk3. After the second hybridization, the cells were washed and visualized with a fluorescence microscope $(\times 400)[56]$. .

\section{Reporter gene assays}

Reporter gene assay for firefly luciferase activity was performed using lysates from transfected cells. The reporter gene vector pRL-SV40 (Promega, Madison, WI) was co-transfected into each cell line, and Renilla luciferase activity generated by this vector was used to normalize the results for transfection efficiency. Cell lysates were prepared by first washing the transfected HEK 293 cells or Cdk3 stably-transfected cells once in PBS at room temperature. After removing PBS completely, 100 $\mu 1$ lysis buffer (Promega Dual Luciferase Reporter Assay System) was added. Then cells were incubated for $1 \mathrm{~h}$ with gentle shaking. The lysates were then transferred into a reaction tube, and the cellular debris was removed by centrifugation. The supernatant fraction was used for the measurement of firefly and Renilla luciferase activity. 20 $\mu 1$ cell lysates were mixed with $100 \mu 1$ Luciferase Assay II reagent, and firefly luciferase light emission was measured by Luminoskan Ascent plate reader (Thermo Electron Corp., Helsinki, Finland). Subsequently, coelenterazine reagent $(100 \mu \mathrm{l})$ containing the substrate for Renilla luciferase light emission was mixed to normalize the firefly luciferase data. The results were expressed as relative AP-1 activity (fold or percentage) as described previously $[57,58]$.

\section{Animal}

A total of 20 female nude $\mathrm{BABL} / \mathrm{c}$ mice (approximately 5 - 6 weeks old) were purchased from Animal Center of Central South University. They were maintained in the Laboratory for Experiments, Central South University under laminar airflow conditions. The studies were conducted according to the standards established by the guidelines of Guangdong Province and approved by the Use Committee for Animal Care [43].

\section{Colon cancer metastasis in nude mice}

The metastatic effect of Cdk3 expression on HT29 cell ex vivo was determined as described previously with some modifications [59]. Briefly, $100 \mu$ laliquots of HT29Cdk3 or TH29-mock suspensions $\left(1 \times 10^{4}\right.$ cells $)$ were mixed with Matrigel, and then respectively injected into the tail veins of nude mice (10 mice per group). These mice were bred for 60 days. After 60 days, the mice were sacrificed, and the metastasis was observed in lung, liver and lymph nodes $[43,60]$. Metastasis was evaluated by measuring weight of metastasized tumors at the lung and liver.

\section{ACKNOWLEDGMENTS}

We thank Dr. Barrett J. Rollins for kindly providing the pRcCMV-HA-Cdk3 plasmids, also thank Dr. Dirk Bohmann for providing pHis6-tagged c-Jun. We appreciate the contributions and helpful discussion of various members in the Zigang Dong Lab.

\section{GRANT SUPPORT}

This work was supported by the National Natural Science Foundation of China (81372282, 81000881, 81402368, 81402265 and 81502346), Zhuhai Best Medical Instrument Appliance Inc., and the Foundation of State Key Laboratory of Oncology in South China (HN2011-04). 


\section{CONFLICTS OF INTEREST}

The authors disclose no potential conflict of interest.

\section{REFERENCES}

1. Jemal A, Bray F, Center MM, Ferlay J, Ward E, Forman D. Global cancer statistics. CA Cancer J Clin. 2011; 61:69-90.

2. Ku G, Tan IB, Yau T, Boku N, Laohavinij S, Cheng AL, Kang YK, de Lima Lopes G, Jr. Management of colon cancer: Resource-stratified guidelines from the asian oncology summit 2012. Lancet Oncol. 2012; 13:e470-481.

3. Siegel R, Ma J, Zou Z, Jemal A. Cancer statistics, 2014. CA Cancer J Clin. 2014; 64:9-29.

4. Ferlay J, Shin HR, Bray F, Forman D, Mathers C, Parkin DM. Estimates of worldwide burden of cancer in 2008: Globocan 2008. Int J Cancer. 2010; 127:2893-2917.

5. Baena R, Salinas P. Diet and colorectal cancer. Maturitas. 2015; 80:258-264.

6. Stein U, Schlag PM. Clinical, biological, and molecular aspects of metastasis in colorectal cancer. Recent Results Cancer Res. 2007; 176:61-80.

7. DeSantis $\mathrm{CE}$, Lin $\mathrm{CC}$, Mariotto $\mathrm{AB}$, Siegel RL, Stein KD, Kramer JL, Alteri R, Robbins AS, Jemal A. Cancer treatment and survivorship statistics, 2014. CA Cancer J Clin. 2014; 64:252-271.

8. Brenner H, Kloor M, Pox CP. Colorectal cancer. Lancet. 2014; 383:1490-1502.

9. Koelzer VH, Herrmann P, Zlobec I, Karamitopoulou E, Lugli A, Stein U. Heterogeneity analysis of metastasis associated in colon cancer 1 (macc1) for survival prognosis of colorectal cancer patients: A retrospective cohort study. BMC Cancer. 2015; 15:160.

10. Fritzmann J, Morkel M, Besser D, Budczies J, Kosel F, Brembeck FH, Stein U, Fichtner I, Schlag PM, Birchmeier W. A colorectal cancer expression profile that includes transforming growth factor beta inhibitor bambi predicts metastatic potential. Gastroenterology. 2009; 137:165-175.

11. Fearon ER. Molecular genetics of colorectal cancer. Annu Rev Pathol. 2011; 6:479-507.

12. Nurnberg A, Kitzing T, Grosse R. Nucleating actin for invasion. Nat Rev Cancer. 2011; 11:177-187.

13. Yang K, Jiang L, Hu Y, Yu J, Chen H, Yao Y, Zhu X. Short hairpin rna- mediated gene knockdown of foxm1 inhibits the proliferation and metastasis of human colon cancer cells through reversal of epithelial-to-mesenchymal transformation. J Exp Clin Cancer Res. 2015; 34:40.

14. Shen Z, Deng H, Fang Y, Zhu X, Ye GT, Yan L, Liu H, Li $\mathrm{G}$. Identification of the interplay between sox 9 and s100p in the metastasis and invasion of colon carcinoma. Oncotarget. 2015; 6:20672-20684. doi: 10.18632/oncotarget.3967.

15. Braun K, Holzl G, Soucek T, Geisen C, Moroy T, Hengstschlager M. Investigation of the cell cycle regulation of Cdk3-associated kinase activity and the role of cdk3 in proliferation and transformation. Oncogene. 1998; 17:22592269.

16. van den Heuvel S, Harlow E. Distinct roles for cyclindependent kinases in cell cycle control. Science. 1993; 262:2050-2054.

17. Ren S, Rollins BJ. Cyclin c/cdk3 promotes rb-dependent G0 exit. Cell. 2004; 117:239-251.

18. Keezer SM, Gilbert DM. Evidence for a pre-restriction point Cdk3 activity. J Cell Biochem. 2002; 85:545-552.

19. Hofmann F, Livingston DM. Differential effects of cdk2 and $\mathrm{Cdk} 3$ on the control of prb and e2f function during $\mathrm{g} 1$ exit. Genes Dev. 1996; 10:851-861.

20. Cui J, Yang Y, Li H, Leng Y, Qian K, Huang Q, Zhang C, Lu Z, Chen J, Sun T, Wu R, Sun Y, Song H, Wei X, Jing P, Yang X. Mir-873 regulates eralpha transcriptional activity and tamoxifen resistance via targeting $\mathrm{Cdk} 3$ in breast cancer cells. Oncogene. 2015; 34:3895-3907.

21. Wang L, Hu HY, Lin YL, Zhao ZX, Tan L, Yu P, Wan HJ, Jin Z, Zheng D. Cdk3 expression and its clinical significance in human nasopharyngeal carcinoma. Mol Med Rep. 2014; 9:2582-2586.

22. Hu H, Lin Y, Yu P, Zhao Z, Wang L, Nie G, Zheng D. Cdk3 expression and its clinical significance in human nasopharyngeal carcinoma. [Article in Chinese]. Lin Chung Er Bi Yan Hou Tou Jing Wai Ke Za Zhi. 2013; 27:958-960.

23. Zheng D, Cho YY, Lau AT, Zhang J, Ma WY, Bode AM, Dong Z. Cyclin-dependent kinase 3-mediated activating transcription factor 1 phosphorylation enhances cell transformation. Cancer Res. 2008; 68:7650-7660.

24. Cho YY, Tang F, Yao K, Lu C, Zhu F, Zheng D, Pugliese A, Bode AM, Dong Z. Cyclin-dependent kinase-3-mediated c-jun phosphorylation at ser63 and ser73 enhances cell transformation. Cancer Res. 2009; 69:272-281.

25. Wang J, Kuiatse I, Lee AV, Pan J, Giuliano A, Cui X. Sustained c-jun-nh2-kinase activity promotes epithelialmesenchymal transition, invasion, and survival of breast cancer cells by regulating extracellular signal-regulated kinase activation. Mol Cancer Res. 2010; 8:266-277.

26. Nam EH, Lee Y, Moon B, Lee JW, Kim S. Twist1 and ap-1 cooperatively upregulate integrin alpha5 expression to induce invasion and the epithelial-mesenchymal transition. Carcinogenesis 2015; 36:327-337.

27. Jiang WG, Sanders AJ, Katoh M, Ungefroren H, Gieseler F, Prince M, Thompson SK, Zollo M, Spano D, Dhawan P, Sliva D, Subbarayan PR, Sarkar M, et al. Tissue invasion and metastasis: Molecular, biological and clinical perspectives. Semin Cancer Biol. 2015; 35 Suppl:S244-75.

28. Ding X, Pan H, Li J, Zhong Q, Chen X, Dry SM, Wang CY. Epigenetic activation of AP-1 promotes squamous cell carcinoma metastasis. Sci Signal. 2013; 6:ra28 21-13, S2015.

29. Kappelmann M, Bosserhoff A, Kuphal S. Ap-1/c-jun transcription factors: Regulation and function in malignant melanoma. Eur J Cell Biol. 2014; 93:76-81. 
30. Peng B, Zhu H, Ma L, Wang YL, Klausen C, Leung PC. Ap-1 transcription factors c-fos and c-jun mediate gnrhinduced cadherin-11 expression and trophoblast cell invasion. Endocrinology. 2015; 156:2269-2277.

31. Kwon GT, Cho HJ, Chung WY, Park KK, Moon A, Park $\mathrm{JH}$. Isoliquiritigenin inhibits migration and invasion of prostate cancer cells: Possible mediation by decreased JNK/ AP-1 signaling. J Nutr Biochem. 2009; 20:663-676.

32. Lee JY, Lee HS, Lee DC, Chu SH, Jeon JY, Kim NK, Lee JW. Visceral fat accumulation is associated with colorectal cancer in postmenopausal women. PloS one. 2014; 9:e110587.

33. Bullrich F, MacLachlan TK, Sang N, Druck T, Veronese ML, Allen SL, Chiorazzi N, Koff A, Heubner K, Croce CM. Chromosomal mapping of members of the $\mathrm{Cdc} 2$ family of protein kinases, Cdk3, Cdk6, pisslre, and pitalre, and a cdk inhibitor, p27kip1, to regions involved in human cancer. Cancer Res. 1995; 55:1199-1205.

34. Chellappan SP, Hiebert S, Mudryj M, Horowitz JM, Nevins JR. The E2F transcription factor is a cellular target for the rb protein. Cell. 1991; 65:1053-1061.

35. Schang LM, Bantly A, Schaffer PA. Explant-induced reactivation of herpes simplex virus occurs in neurons expressing nuclear Cdk2 and Cdk4. J. Virol. 2002; 76:77247735 .

36. Hengstschlager M, Braun K, Soucek T, Miloloza A, Hengstschlager-Ottnad E. Cyclin-dependent kinases at the G1-s transition of the mammalian cell cycle. Mutat Res. 1999; 436:1-9.

37. Ouelaa-Benslama R, De Wever O, Hendrix A, Sabbah M, Lambein K, Land D, Prevost G, Bracke M, Hung $\mathrm{MC}$, Larsen AK, Emami S, Gespach C. Identification of a galphagbetagamma, AKT and pkcalpha signalome associated with invasive growth in two genetic models of human breast cancer cell epithelial-to-mesenchymal transition. Int J Oncol. 2012; 41:189-200.

38. Miyanishi K, Takayama T, Ohi M, Hayashi T, Nobuoka A, Nakajima T, Takimoto R, Kogawa K, Kato J, Sakamaki $\mathrm{S}$, Niitsu Y. Glutathione s-transferase-pi overexpression is closely associated with k-ras mutation during human colon carcinogenesis. Gastroenterology. 2001; 121:865-874.

39. Angel P, Karin M. The role of jun, fos and the AP-1 complex in cell-proliferation and transformation. Biochim Biophys Acta. 1991; 1072:129-157.

40. Banskota S, Regmi SC, Kim JA. Nox1 to nox2 switch deactivates ampk and induces invasive phenotype in colon cancer cells through overexpression of MMP-7. Mol Cancer. 2015; 14:123.

41. Tang F, Zou F, Peng Z, Huang D, Wu Y, Chen Y, Duan C, Cao Y, Mei W, Tang X, Dong Z. N,n'-dinitrosopiperazinemediated ezrin protein phosphorylation via activation of rho kinase and protein kinase $\mathrm{c}$ is involved in metastasis of nasopharyngeal carcinoma 6-10B cells. J Biol Chem. 2011; 286:36956-36967.
42. Lin $\mathrm{CH}$, Shih $\mathrm{CH}$, Tseng CC, Yu CC, Tsai YJ, Bien MY, Chen BC. Cxcl12 induces connective tissue growth factor expression in human lung fibroblasts through the Rac/ERK, jnk, and ap-1 pathways. PloS one. 2014; 9:e104746.

43. Tang F, Wang D, Duan C, Huang D, Wu Y, Chen Y, Wang W, Xie C, Meng J, Wang L, Wu B, Liu S, Tian $\mathrm{D}$, et al. Berberine inhibits metastasis of nasopharyngeal carcinoma $5-8 \mathrm{~F}$ cells by targeting rho kinase-mediated ezrin phosphorylation at threonine 567. J Biol Chem. 2009; 284:27456-27466.

44. Cheng AL, Huang WG, Chen ZC, Zhang PF, Li MY, Li F, Li JL, Li C, Yi H, Peng F, Duan CJ, Xiao ZQ. Identificating cathepsin $\mathrm{D}$ as a biomarker for differentiation and prognosis of nasopharyngeal carcinoma by laser capture microdissection and proteomic analysis. J Proteome Res. 2008; 7:2415-2426.

45. Li Y, Lu J, Peng Z, Tan G, Liu N, Huang D, Zhang Z, Duan C, Tang X, Tang F. N,n'-dinitrosopiperazine-mediated AGR2 is involved in metastasis of nasopharyngeal carcinoma. PLoS One. 2014; 9:e92081.

46. Attiga FA, Fernandez PM, Weeraratna AT, Manyak MJ, Patierno SR. Inhibitors of prostaglandin synthesis inhibit human prostate tumor cell invasiveness and reduce the release of matrix metalloproteinases. Cancer Res. 2000; 60:4629-4637.

47. Dong Z, Lavrovsky V, Colburn NH. Transformation reversion induced in JB6 RT101 cells by AP-1 inhibitors. Carcinogenesis 1995; 16:749-756.

48. Sun Y, Dong Z, Nakamura K, Colburn NH. Dosagedependent dominance over wild-type p53 of a mutant p53 isolated from nasopharyngeal carcinoma. Faseb J. 1993; 7:944-950.

49. Musti AM, Treier M, Bohmann D. Reduced ubiquitindependent degradation of c-jun after phosphorylation by map kinases. Science. 1997; 275:400-402.

50. Zhu F, Choi BY, Ma WY, Zhao Z, Zhang Y, Cho YY, Choi HS, Imamoto A, Bode AM, Dong Z. Cooh-terminal src kinase-mediated c-jun phosphorylation promotes c-jun degradation and inhibits cell transformation. Cancer Res. 2006; 66:5729-5736.

51. Zhang Y, Dong Z, Nomura M, Zhong S, Chen N, Bode AM. Signal transduction pathways involved in phosphorylation and activation of p70s6 $\mathrm{k}$ following exposure to uva irradiation. J Biol Chem. 2001; 276:20913-20923.

52. Zhang Y, Zhong S, Dong Z, Chen N, Bode AM, Ma W. Uva induces ser381 phosphorylation of p90RSK/MAPKAP-K1 via erk and jnk pathways. J Biol Chem. 2001; 276:1457214580 .

53. Cheng AL, Huang WG, Chen ZC, Peng F, Zhang PF, Li MY, Li F, Li JL, Li C, Yi H, Yi B, Xiao ZQ. Identification of novel nasopharyngeal carcinoma biomarkers by laser capture microdissection and proteomic analysis. Clin Cancer Res. 2008; 14:435-445.

54. Li M, Xiao ZQ, Chen ZC, Li JL, Li C, Zhang PF, Li MY. 
Proteomic analysis of the aging-related proteins in human normal colon epithelial tissue. J Biochem Mol Biol. 2007; 40:72-81.

55. Zhang Y, Ma WY, Kaji A, Bode AM, Dong Z. Requirement of ATM in UVA-induced signaling and apoptosis. J Biol Chem. 2002; 277:3124-3131.

56. Peng Z, Liu N, Huang D, Duan C, Li Y, Tang X, Mei W, Zhu F, Tang F. N,n'-dinitrosopiperazine - mediated heatshock protein 70-2 expression is involved in metastasis of nasopharyngeal carcinoma. PLoS One. 2013; 8:e62908.

57. Huang C, Ma WY, Dong Z. Requirement for phosphatidylinositol 3-kinase in epidermal growth factorinduced AP-1 transactivation and transformation in jb6 p+ cells. Mol Cell Biol. 1996; 16:6427-6435.

58. Li JJ, Dong Z, Dawson MI, Colburn NH. Inhibition of tumor promoter-induced transformation by retinoids that transrepress AP-1 without transactivating retinoic acid response element. Cancer Res. 1996; 56:483-489.

59. Mitani N, Murakami K, Yamaura T, Ikeda T, Saiki I. Inhibitory effect of berberine on the mediastinal lymph node metastasis produced by orthotopic implantation of lewis lung carcinoma. Cancer Lett. 2001; 165:35-42.

60. Tang FQ, Duan CJ, Huang DM, Wang WW, Xie CL, Meng JJ, Wang L, Jiang HY, Feng DY, Wu SH, Gu HH, Li MY, Deng FL, et al. HSP70 and mucin 5B. Novel protein targets of n,n'-dinitrosopiperazine-induced nasopharyngeal tumorigenesis. Cancer Sci. 2009; 100:216-224. 